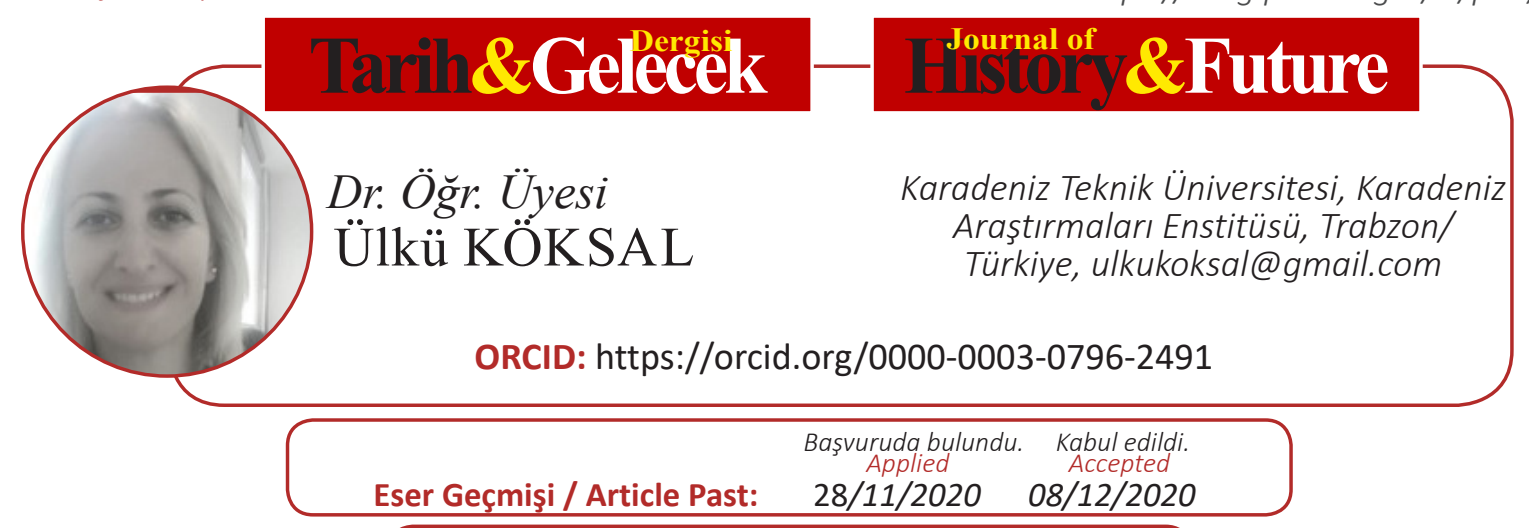

Araştırma Makalesi

DOI: http://dx.doi.org/10.21551/jhf.832630

Research Paper

Orjinal Makale / Orginal Paper

\title{
Büyük Harp’ten Milli Mücadele’ye Basında Kadın ve Kadınlık Tartışmaları*
}

Öz

\author{
Discussion of Women and Femininity in the Press in the Period \\ from the Great War to the National Struggle
}

Tanzimat Dönemi ile birlikte yaşanan değişimler geleneksel Osmanlı toplum yapısında ve kadının toplumsal hayattaki konumunda farklılaşmaya neden olmuştur. II. Meşrutiyet Dönemi'nde hız kazanan değişimler neticesinde kadın meselesi basında sıkça tartışılmaya başlandı. Bu dönemde kadınlar pek çok dernekte faal olarak yer alırken kadın dernekleri de oluşturulmuştur. Ayrıca birçok kadın dergisi yayına başlayarak kadın ve kadınlık meselesi kamuoyunun gündemine yerleşmiştir.

I. Dünya Savaşı kadının kamu hayatındaki konumunun şekillenmesinde önemli bir merhaledir. Kadın aslında savaş yazılarının ve analizlerinin önemli bir başlığıdır. Ancak genelde savaş alanının yani cephenin değil cephe gerisinin kahramanıdır. Kadınların savaşta aldıkları yeni roller, faaliyetleri, güç ve yeteneklerini ispat etmeleri, erkeklerin mağrur ve baskın rollerini törpülemiştir. Nitekim "kadınlar ve kadınlık meselesi”, kadın hakları ve kadın hareketleri ekseninde tüm dünyada olduğu gibi Osmanlı basınının önemli konularından biri haline gelmiştir. Kadınların sosyal ve ekonomik faaliyetlerin içinde yer alması ve kamu hayatına daha da aktif şekilde dahil olması sonucunda zihniyet, giyim-kuşam ve yaşam tarzında ortaya çıkan değişimler bu durumu onaylayanlar ile uygun bulmayanlar arasındaki tartışmaları alevlendirmiştir. Milli Mücadele yıllarında da devam eden bu tartışmalar çeşitli kadın dergileri ve ulusal basındaki gazete ve mecmualarda sıklıkla bahsedilen konulardandır.

Bu çalışmada I. Dünya Savaşı ve Milli Mücadele yıllarında kadın ve kadınlık meselesine dair basında yer alan tartışmalara yer verilmiştir. Bu çerçevede Kadınlar Dünyası, Servet-i Fünûn, Sebilürreşad, Büyük Mecmua, İçtihad, Muallim, Íslam Mecmuası vb. dergi ve mecmualar, Tasvir-Efkar, Alemdar, İstiklal gibi ulusal gazeteler ile çeşitli kitap ve makalelerden faydalanılmıştır.

Anahtar Kelimeler: I. Dünya Savaşı, Kadın, Kadınlık, Basın, Milli Mücadele.

* Bu çalışma, 11-14 Haziran 2019 tarihleri arasında Samsun'da düzenlenen 100. Yılında 19 Mayıs ve Millî Mücadele Uluslararası Sempozyumu'nda sunulmuş tebliğin gözden geçirilmiş ve genişletilmişs şeklidir. 


\section{Abstract}

The changes that occurred with the Tanzimat period led to a differentiation in the traditional Ottoman social structure and the position of women in social life. As a result of the increasing changes in the Second Constitutional period, the issue of women began to be discussed frequently in the press. During this period, women were active in many associations, and women's associations were also created. In addition, many women's magazines started to be published, and the issue of women and femininity settled on the public agenda.

The First World War was an important step in shaping the position of women in public life. In fact, woman is an important title of war related articles and war analysis. However, in general, women are not the heroes of the front lines of the battlefield, but of the hinterland. The fact that women demonstrated their new roles, activities, power and abilities in the war has undermined the proud and dominant roles of men. As a matter of fact, "women and the issue of femininity" became one of the important issues of the Ottoman press, as it was all over the world on the axis of women's rights and women's movements. As a result of women's participation in social and economic activities and even more active participation in public life, changes in women's mindset, clothing and lifestyle ignited discussions between those who approved this situation and those who did not consider it appropriate. These debates, which continued during the years of the national struggle, were frequently mentioned in various women's magazines and newspapers and journals in the National Press.

The debates on the issue of women and femininity that took place in the press during the First World War and the War of Independence were included in this study. In this context, magazines and journals such as "Kadınlar Dünyası, Servet-i Fünûn, Sebilürreşad, Büyük Mecmua, İçtihad, Muallim, İslam Mecmuası”, national newspapers such as Tasvir-Efkar, Alemdar, Istiklal, as well as various books and articles were used.

Keywords: First World War, Women, Femininity, Press, National Struggle.

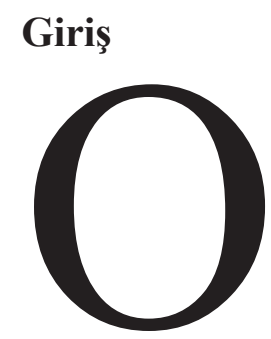

smanlı Devleti'nin 19. yüzyılda geçirdiği değişimler kadının toplumsal konumunu da etkiledi. Tanzimat Dönemi’nde kız çocuklarının ortaöğretim imkânlarına kavuşması ve mesleki eğitim kurumlarında yetişmeleri en köklü yeniliklerdendi. ${ }^{1}$ Mesleki ve kültürel açıdan gelişmelerinin yanı sıra kadınlara yeni haklar tanınması toplumsal konumlarının geleneksel kalıplardan sıyrılmaya başlamasında önemli aşamalardandı. Osmanlı Devleti modernleşme sürecinde canlı bir basın yayın hayatına sahne oldu. Kadın meselesi 19. yüzyılın ikinci yarısından itibaren dönemin aydın ve yazarları tarafından sıklıkla ele alınan konular arasında yer aldı. Bu süreçte pek çok eserde kadın-erkek ilişkileri, kadının ailedeki konumu, eğitimi, sosyal statüsü, hakları gibi konular irdelendi. Dönemin erkek aydın ve yazarlarının başlattığ bu fikri mücadeleye zamanla kadınlar da dahil oldu. Kadın dergilerinin de yayına başladığı bu dönemde kadın ve kadınlık meselesi

1 Niyazi Berkes, Türkiye’de Çă̆daşlaşma, yay. haz. Ahmet Kuyaş, 18. Baskı, Yapı Kredi Yayınları, İstanbul 2012, s. 231. 
gelenekçilerle batılılaşma yanlıları arasındaki fikir çatışmasının önemli bir parçasını oluşturdu. ${ }^{2}$

II. Meşrutiyet Dönemi'nde kadınlar tartışmalarda daha aktif olarak yer almaya başladı. Bu süreçte kadının yalnızca rol ve görevlerinin sorgulanması ve hak taleplerinin dile getirilmesiyle kalınmamış, aynı zamanda kamusal alana dahil olmalarına dair örnekler de artmıştı. Alınan eğitim ve dönemin şartlarının da etkisiyle çalışma hayatına dâhil olan kadınlar pek çok dernekte aktif rol alıp almış, hatta kadın dernekleri kurmuşlardı. Dolayısıyla artık talep ve temenniler pratiğe dökülmeye başlamıştı. ${ }^{3}$

I. Dünya Savaşı yıllarında, Türk basınında kadınlığa dair yazılar ve ortaya çıkan tartışmaların dönemin olağanüstü koşullarına bağlı olarak şekillendiği görülmektedir. Nitekim meseleye dair tartışmalar, savaş koşullarının getirdiği bir sonuç olarak kadının çalışma hayatına dahil olması, yaşam tarzında, giyim kuşamında ortaya çıkan değişiklikler, mesleki eğitim başta olmak üzere yükseköğretimde yer alması, aile içindeki konumu, görevleri ve siyasi hakları gibi başlıklar altında sürdürüldü. Kadın ve kadınlık, söz konusu başlıklar altında I. Dünya Savaşı yılları fikir hayatııın en ruhlu ve heyecanlı konuları arasinda yer aldı. ${ }^{4}$

\section{Kadının Eğitimi}

Kadının toplumsal konumunu sorgulayan dönemin pek çok yazar ve aydınına göre kadınlı̆̆ın ilerlemesindeki en büyük engel erkeğin tahakkümüydü. Onlara göre toplumda kadına değer verilmemekteydi. Nitekim sosyal hayatta girişken olmamaları ve erkeklere muhtaç bir yaşam tarzına mecbur bırakılmaları zengin-fakir bütün kadınların kaderiydi. Yapılan değerlendirmelere göre kadının yeterli eğitim imkânlarına kavuşmaması veya kendi ekonomik özgürlüğüne sahip olmaması erkeğin tahakkümüne mahkûm olması sonucunu doğurmuştu. Oysa kadın ev ve aile dışında, kamu hayatında da yer almalıydı. Neticede kadınlar zekâ konusunda erkeklerle eşit seviyedeydi. ${ }^{5}$ Kimi yazarlara göre kadınların büyük kısmının eğitim imkanlarından mahrum kalması ruhlarının daha da ezilmesine neden olmaktaydı. Kız çocuklarının eğitim hakkını kullanamaması muhafazakar

2 Berkes, a.g.e., s. 373; Şefika Kurnaz, Cumhuriyet Öncesinde Türk Kadını (1839-1923), 2. Bask1, T.C. Başbakanlık Aile Araştırma Kurumu Başkanlığı Yayınları, Ankara 1991, s. 5-44. Fatma Aliye Hanım dönemin öncü kadın yazarlarındandır. Tanzimat Dönemi’nde şair ve edip olarak Makbule Leman Hanım ve Şair Nigar Hanımlar da çeşitli eserler vermiştir. Fatma Aliye Hanım’ın kardeşi Emine Semiye Hanım da kadın hakları savunucularındandır. Sonraki yıllarda Halide Edip ve Nezihe Muhiddin seslerini yükselten kadın aydınlar arasında yer almıştır. Bu öncülere bakıldığında genellikle aristokrat ve yönetici zümrenin eş ve çocukları oldukları, bu anlamda iktidara yakın olmaları dikkat çekicidir. Mensup oldukları aileler dolayısıyla iyi eğitim almış ve birkaç dil bilen aydın kadınlardır. Yaprak Zihnioğlu, Kadınsız İnkılap: Nezihe Muhiddin, Kadınlar Halk Fırkası, Kadın Birliği, Metis Yayınları, İstanbul 2016, s. 43-52.

3 Berkes, a.g.e., s. 444-446; Kurnaz, a.g.e., s. 77-86; Serpil Çakır, Osmanlı Kadın Hareketi, Metis Yayınları, İstanbul 1996, s. 32-78; Leyla Kaplan, Cemiyetlerde ve Siyasi Teşkilatlarda Türk Kadını (19081960), Atatürk Araştırma Merkezi Yayınları, Ankara 1998, s. 24-70; Zafer Toprak, Türkiye'de Kadın Özgürlüğ̈̈ ve Feminizm (1908-1935), Tarih Vakfı Yurt Yayınları, İstanbul 2016, s. 18-26; Zihnioğlu, a.g.e., s. 57-63. II. Meşrutiyet Dönemi'nde Osmanlı basınında kadın ve kadınlık konusundaki tartışmalara dair bir çalışma için bk. Ümüt Akagündüz, "Kadın ve Kadınlığa Dair II. Meşrutiyet Dönemi Dergilerinden Yansımalar (1908-1918)", Folklor/ Edebiyat, 19/73 (2013/1), s. 63-80.

4 Fevziye Abdürreşid, “İslam İçtimaiyatı: Kadın Meselesi”, İslam Mecmuası, c. 4, S. 53, 15 Mayıs 1333 (1917), s. 1054-1058.

5 “Erkeklerin Hükmü Kadınların Aczi”, Kadınlar Dünyası, S. 141, 2 Mayıs 1330 (15 Mayıs 1914), s. 7-8. 
ebeveynlerin ve özellikle babaların hatası olarak değerlendiriliyordu. ${ }^{6}$ Servet-i Fünûn dergisinde fikirlerini ifade eden Fatma Aliye Hanım bir yazısında kadınların savaş sırasında hastabakıcı olarak çalışmalarını takdirle ifade etmiş, onların bu fedakârlığının dönemin en önemli ihtiyaçlarından birini karşıladığını belirtmişti. Ona göre "Türk kadınının kahramanlığı” olarak değerlendirilebilecek bu durum kadının eğitimi ve sosyal hayata karışması için savaş yıllarına kadar verilen mücadelenin ne kadar haklı olduğunu göstermişti. ${ }^{7}$

Fatma Aliye Hanım Servet-i Fünûn'da yer alan bir başka yazısında geçmişte İslam Medeniyeti'nde kadına ve onun eğitimine önem verildiğini, fakat şimdi Türk kadınının hayatında geriye gidiş söz konusu olup cahilliğin arttığını ve halk arasında kadınlara eğitim hakkı verilmesinin doğru olmadığını iddia ederek koyu Müslüman olduğunu savunanlar ortaya çıktığını ifade etmişti. Hz. Muhammed' in “İlim Çin'de de olsa alınız." sözünü hatırlatan yazara göre savaş gibi olağanüstü durumlarda nüfusun diğer yarısının geçim kaygısına düşmesi biraz da kadının eğitiminin sekteye uğramasındand $1 .{ }^{8}$ İslam'ın kadına yüksek bir mertebe verdiğini ifade edenler arasında İnas İdadisi Müdüresi Fatma Şevket Hanım da yer alarak kadınlığı birbirinden farklı üç devreye ayırmıştı: Kızlık, zevcelik, validelik. Bunlardan kızlık devresinde ebeveynlerin ayırım yapmadan kız çocuklarının eğitimine de önem vermesini öneriyor, ilerde evlilik hayatında eşiyle uyum içinde yaşayabilmesi için bunun son derece gerekli olduğunu vurguluyordu. Annelik ise en kutsal ve ihmal edilmemesi gereken görevdi. Fatma Şevket Hanım'a göre kadın ıslah edilirse hayat-1 aile tenvir edilmiş olacaktı. ${ }^{9}$

Yusuf Razi İstiklâl gazetesinde Harp ve Kadınlar başlıklı yazısında kızların küçük yaştan itibaren iyi eğitim almalarını, hesap, ilm-i eşya dersleri verilerek günlük hayatı tanımalarının sağlanmasını, ticaret ve sanayi alanında çalışmak isteyen ve ailesinin geçimini temin etmek isteyen kadınların namusuyla ve alın teriyle para kazanmasına engel olunmamasını ve her türlü sözlü ve fiili saldırıdan korunmasını önermişti. Yazar ayrıca orta ve düşük gelirli aile kızlarının terbiye ve eğitiminde tahsilli, görgülü yüksek tabaka hanımlarının desteğinin fayda sağlayacağı düşüncesindeydi. ${ }^{10}$

Dönemin aydınlarından Celal Nuri Bey kadının eğitim almasının toplumsal yapıda önemli bir ilerleme sağlayacağı görüşündeydi. Ona göre toplumun temeli olan ailenin sağlam olması özellikle kadının sosyal ve ekonomik kudretine bağlıydı. Bu nedenle onun eğitimi ordu, donanma ve diyanet kadar önemli addedilmeliydi. ${ }^{11}$

6 Feride İzzet Selim, "Kadınlarımızda Lüzum-1 Tahsil”, Kadınlar Dünyası, S. 160, 10 Kânûn-1 Sânî 1330 (23 Ocak 1915), s. 4-5.

7 Fatma Aliye, “Kahraman Kadınlarımız”, Servet-i Fünûn, c. 49, S. 1253, 28 Mayıs 1331 (10 Haziran 1915), s. 66-67. Avrupa ülkelerinde savaşın kadının yaşamında meydana getirdiği değişiklikler ve savaştaki rolü de dönemin basınında sıklıkla yer buldu. Ahmet Köksal, "Savaş ve Duygusal Değişim: Birinci Dünya Savaşı'nın Sonunda Osmanlı Basınından Bir Panorama Denemesi”, Zamanın İzleri: 100. Yllında Birinci Dünya Savaşı, Karadeniz Teknik Üniversitesi Yayınları, Trabzon 2015, s. 103-121.

8 Fatma Aliye, "Kadınlar Hakkında”, Servet-i Fünûn, c. 50, S. 1289, 18 Şubat 1331( 4 Mart 1916), s. 178179.

9 Fatma Şevket, "Münevver Kadınlığın İhzarı”, Muallim, S. 2, 5 Kânûn-1 Evvel 1331 (18 Aralık 1915).

10 Yusuf Razi, “"Harpten Sonra Kadınlar”, İstiklâl, S. 105, 8 Nisan 1335 (1919).

11 Necmi Uyanık, "Batıcı bir Aydın Olarak Celal Nuri İleri ve Meşrutiyet’ten Cumhuriyet’e Türk Kadınına Bakışı”, Selçuk Üniversitesi Türkiyat Araştırmaları Dergisi, S. 36, (Güz 2014), s. 144. 
Savaş koşulları kadının o döneme kadar kamuda genellikle öğretmenlik temelinde şekillenen mesleki eğitimini çeşitlendirmişti. Zira cephelerde ortaya çıkan kayıplar ve yaralı sayılarının artması özellikle sağlık alanında çalışacak elemanlara daha fazla ihtiyaç duyulmasına neden oldu.1916 yılı yazında Sıhhiye Meclis-i Umumisi önemli bir karar alarak artık kadınların da tababet icra etmelerine izin verdiğini açıkladı. Maarif Nezareti de kadınların fakülteye devam etmelerinin önünü açan bir karar aldı. Bu gelişmeler kamuoyunda kadınlık hayatında yeni ufuklar açılacağına olan inancı arttırdı. Aynı yıl Kız Darülfünunu'ndan mezun olan 8 kadın öğretmen İstanbul ve taşradaki okullarda görevlendirildi. ${ }^{12} \mathrm{Bu}$ süreçte Maarif Nezaretinin çalışmaları ile kadınlara özel olarak ticaret dersleri de verilmeye başlandı. 1917 yılında başlayan eğitim sürecinin bir yıl olması, kadınlara genel ticaret bilgisinin yanı sıra Daktilografi, Usul Defteri, Türkçe, Hesap, rakam ve harfleri anlayabilecek kadar Fransızca gibi derslerin verilmesi planland1. ${ }^{13}$

Türk kadını yükseköğrenim imkânına I. Dünya Savaşı yıllarında kavuştu. ${ }^{14}$ Savaşın başlarında kadın haklarına dair tartışmaları alevlendiren en önemli gelişme Darülfünun'da karma eğitime geçilmesiydi. ${ }^{15}$ İkdam başta olmak üzere İstanbul basınında konuya olumlu yaklaşan yazılar yayımlandı. Taşra basınında da bu konuda değerlendirmeler yapılmış, karma eğitim meselesi gelenekçi bir yaklaşımla ele alınmıştı. İstanbul'da yayımlanan İkdam gazetesinde Darülfunun'da karma eğitime geçilmesinin medeniyet açısından bir ilerleme olarak görülmesi taşra basınında eleştirilmişti. Konya'da yayımlanan İbret gazetesindeki değerlendirmeye göre kadının özenle yetiştirilmesi toplumda gerçek anlamda ilerlemeyi sağlayacaktı. Zira geçmişte iyi yetişmiş bir kadının yetiştirdiği erkekler ilimde öncü olmuştu. Kadın bu vazifesini anlayıp ona göre kendisini donatmalıydı. Yoksa Batı'da olduğu gibi hukuki eşitliği savunan kadınlık (feminizm) vazifede de eşitliği dikkate alamadığından medeniyet ilerlemesinden ziyade yıkıcı bir etki yaratacaktı. Bununla birlikte kadının eğitiminde din, akide, ahlak, adet ve ananelere sadık kalınmalıydı. Diğer yandan karma eğitime geçilmesinin yalnızca İstanbul kadınlarına yönelik bir mesele olarak görülmesi de doğru bir yaklaşım olarak görülmemekte böyle önemli bir sosyal meselede taşra kadınlarının da fikrinin sorulması gerektiği üzerinde durulmaktaydı. ${ }^{16}$ Benzer şekilde Trabzon'da yayımlanan Zafer gazetesinde de İkdam gazetesinin karma eğitime dair yorumu eleştirilerek ülkenin yalnızca İstanbul ahalisinden oluşmadı $\breve{g}_{1}$ ifade edilmişti. ${ }^{17}$

Darülfünun'da uygulanan karma eğitim usulünün Milli Mücadele yıllarında ekonomik sebepler gerekçe gösterilerek terk edilmesi ve dershanelerin haremlik selamlık olarak ayrılması basında yeni bir tartışmayı başlatmıştı. ${ }^{18}$ Büyük Mecmua dergisinde bir anket düzenlenerek bu konudaki fikirlerin ifade edilmesi sağlandı. Ankete katılan Halide Edip'e göre Darülfünun'da eğitimin birleştirilmesi Türk kadınının hayatında pek mühim bir inkılap olarak görülerek muhafazakârlarla yenilikçiler arasında tartışma kapısı açmıştı. Ona göre mağazalarda kadın

12 Muallim, S. 15, 15 Teşrîn-i Evvel 1333 (1917), s. 552.

13 Muallim, S. 16, 15 Teşrîn-i Sani, 1333 (1917), s. 583.

14 Berkes, a.g.e., s. 446.

15 Toprak, a.g.e., s. 214-248.

16 Sebilürreşad, c. 16, S. 414-415, 15 Mayıs 1335 (1919), s. 335-336.

17 Toprak, a.g.e., s. 227-228.

18 Maarif Nezaretinin karma eğitimi kaldırma kararının basının büyük bölümünde uygun görülmesi, bu gelişmeyi doğru bulmayanlar tarafından eleştirilen bir husustu. "Teceddüd Adımları", Büyük Мecmиa, S. 4, s. 49; Sabiha Zekeriya, “Kız Darülfünunu Meselesi”, Вüyük Местиa, S. 5, s. 67. 
erkek birlikte satıcıllk yapabiliyorsa Darülfünun dershanelerinde de yan yana oturma hakkına sahipti. Oysa şimdi iktisadi bir temayül gibi başlayıp zamanla geriye gidiş söz konusuydu. Şayet medeni olmaya karar verildiyse fikri müesseselerin de bu yolda ilerlemesi gerekirdi. Müfide Ferid Hanım da kadınların Darülfünun'da karma eğitimden mahrum bırakılsa bile meslek hayatında (Öğretmenlik gibi) erkeklerle aynı çatı altında çalı̧̧acaklarına, dolayısıyla bu usulün terk edilmesinin anlamsızlığına dikkat çekmiş̧i. Feyziye Mektebi Müdiresi Nakiye Hanım da ankete katılıp fikirlerini beyan etmişti. Ona göre irfan müesselerinin kapıları ve beşeri mesai sahaları kadınlara açılmalıydı. Konuya usul açısından yaklaşan Nakiye Hanım kadının sosyal hayatıyla ilgisi olmayan bir komisyonun yaptığı değişiklikle okulun eski haline dönüştürülmesinin doğru olmadığını, bu konunun uzmanlar tarafından kararlaştırılması gerektiğini savundu. Ankete katılan Köprülüzade Mehmed Fuad Bey Darülfünun'da kızların eğitim görmesi üzerine ortaya çıkan yersiz dedikodulara değinerek "teceddüd ve terakki seylini çamurdan sedlerle durdurmak isteyenler çok aldaniyorlar." ifadelerini kullandı. Abdullah Cevdet Bey ise Hz. Muhammed'in ilim tahsil etmenin bütün Müslümanlara farz olduğunu belirten bir hadisinden yola çıarak ibadet nasıl ki kadın erkek birlikte yapılabiliyorsa farz olan eğitimin de aynı şekilde yapılması gerektiğini belirtmişti. Konu ile ilgili fikirlerini Memleket gazetesine verdiği beyanatla açıklayan Rıza Tevfik Bey dünyada kadın ve erkeği hayatta birbirinden ayırmanın mümkün olmadığının uzun zamandır görüldüğünü, Türk sosyal hayatında bu durumun yeni olmasına rağmen kısa sürede memleketi istila ettiğini dile getirip "Bizim Darülfünunumuzda kadın ve erkeğin aynı dersanede ders aldığını göreceğiz. Ben bu hadiseyi ham zihniyetle, asri telakkilere karşı bir aksülamili gibi kabul etmiyorum. Darülfunun müdürü istediği gibi emir verebilir. Fakat ben bir ilan eder kız ve erkek talebeyi diğer bir mahalde toplar konferansımı veririm." diyerek uygulamaya karşı tavrını ortaya koymuştu. Konuya kadın erkek ilişkileri açısından bakan Kazım Nami Bey de: "Kadın erkek ayrı yaşadıkça, (teokratik) milletlerden tevarüs edilen harem hayatı bir müstehase halinde mevcut oldukça ne aile ahlakının, ne de milli ahlakın düzelemeyeceğine inananlardanım." sözleriyle fikrini beyan etmişti. Ankette karma eğitime karşı olduğunu ifade eden Rauf Ahmed Bey: "Vatanımız gibi temeddün (uygarlık) yolunda geri kalmış memleketler için son derecede şayan-1 istifade bir misal teşkil eden Japonya teceddüdü bu Darülfunun meselesinde de ibretbahş bir ders vermektedir. Tesettür meselesi gibi, şekl-i hazırı itibariyle, dini olmaktan ziyade hissi ve ahlaki bir payende ile malul olmayan Japonlar bile işe bir kız Darülfünunu vücuda getirmekle başlamışlardır." diyerek konuyla ilgili önerisini sunuyor, aynı zamanda kamuoyunun fikrinin önemsenmesi gerektiğini de dile getiriyordu. Bununla birlikte Rauf Ahmed Bey meseleyi İslam dinine aykırı görmenin de, taraftarlarını din ve Kanun-i Esasi ahkâmına riayetsizlikle itham etmenin de yanlış olduğunu düşünüyordu. Edebiyat Fakültesi öğrencilerinin konu ile ilgili fikri ise iki tarafa eşitlik tanınması gerektiği yönündeydi. Anket değerlendirmelerine katılan İkdam gazetesine göre kadınların eğitim hakkına bu şekilde engel olunması mantıksızlıkt1. ${ }^{19}$

Sebilürreşad'da yayımlanan bir yazıda Darülfünun'da karma eğitimden vazgeçilmesini eleştiren İfham gazetesine hitaben; “...Kızlarımızın mutlaka erkeklerle beraber okumasının hikmetini bir türlü anlayamadık. Bunda zerre kadar faide görmedik. Bilakis bunda birçok mahzurlar gördük ve bunları uzun uzadıya anlattık. Evet kızlarımızı okutalım, ulum-ı nafia ile teçhiz edelim, fakat erkeklerden ayıralım. Tedrisat-1 muhtelite bize uymaz. Hele bu zamanda hiç uymaz. ...Hem maksat okumak ve okutmak olduktan sonra kızlarımız erkeklerden ayrı okurlarsa 
ne kaybedilir?" ifadelerine yer verilmişti. Kızların tıbbiyeye kabulünün fikri bir zafer olarak görülmesinin de eleştirildiği yazıda zaferin kime karşı kazanıldığı sorulmuştu. Besim Ömer Paşa'nın Tercüman-ı Hakikat gazetesine verdiği beyanattan da bahsedilerek kendisinin karma eğitimden vazgeçilmesinden memnun olacaklar gibi kırgın olacakların da bulunacağını belirtmesi eleştirilen bir başka husustu. ${ }^{20}$

Kadınların eğitiminin medeniyet hayatında ilerlemeyi getireceği düşüncesi dönemin aydın kadınlarının ortak düşüncesidir. Nitekim batılı ülkelerde kadınlar ilk, orta ve yükseköğrenim meselesini çözdükten ve kadının toplumsal hayattaki önemini kamuoyuna benimsettikten sonra önemli haklar ve sosyal statüler kazanmışlardı. Dolayısıyla feminizm Batı'da bir ideal olarak benimsenmişti. Oysa Türk kadınında böyle bir ideal tam olarak oluşmamıştı. Türk kadını için de bu sürecin gerçekleşmesi umulmakla birlikte özellikle Darülfünun'da yeniden ayrı eğitim yapılması karamsarlık tablosu çizmişti. ${ }^{21}$ Sabiha Zekeriya, muhafazakârların her meseleyi olduğu gibi karma eğitimi de din meselesi haline getirmelerini doğru bulmamıştı. ${ }^{22} \mathrm{Bu}$ süreçte konunun din meselesi olmadığını ifade edip acele kararlar verilmesini doğru bulmayan erkekler de fikirlerini dile getirdi. ${ }^{23}$ Kadınların kamu hayatına girmesi, rey hakkı elde etmek için çabalaması geleneksel anlayışa bağlı erkekler tarafından dirençle karşılaşmıştı. Bunun yanında eski kuşak kadınlarının yeni durum hakkında neler düşündüğü de dönemin basınında yer buldu. Büyük Mecmua kadınların ticarethanelerde, devlet dairelerinde çalışması, eğitim kurumlarında erkeklerin yanında öğrenim görmesi gibi gelişmelere alışık olmayan yaşlı kadınların bu durumu onaylayan görüşlerini de okuyucularıyla paylaşmıştı. ${ }^{24}$

Milli Mücadele yıllarında çeşitli kurslarla kadının aydınlanması için çaba sarf edildi. Türk Kadını Dershanesi adıyla açılan kursta her Cuma günü ilmi ve edebi sohbetler düzenlenerek kadının terakkisine çalışıldı. Bu gelişmenin haber olarak verildiği bir yazıda yalnızlığın kişilere sosyal hayatın gerektirdiği becerileri sağlayamayacağı vurgulanarak bu tarz kültür kurumları ile kadının sosyal hayata dâhil olup fikri ve kültürel gelişimine katkı sağlanacaktı. ${ }^{25}$ Aynı dönemde yükseköğrenimde çeşitli alanlarda yapacakları ihtisaslar ve sonrasında meslek hayatında karşılaşabilecekleri güçlükler de ortaya konuyordu. Nitekim bir başka yazıda kadınların tıp eğitimi alması uygun görülmekle birlikte uzun süren eğitimin zorluğu ve meslek hayatında kadın doktorların karşılaşabileceği güçlükler dile getirilmişti. ${ }^{26}$ Kadınların yükseköğretimde, tıp alanında yer almaları kimi yazarlarca memnuniyetle karşıland1. ${ }^{27}$

Savaşın sonlarında kadın meselesinin unutulduğunu düşünen aydınlar konunun önemine yeniden dikkat çekmek istemiş, basını bu yönde yayınlar yapmaya davet etmişti. Bu faaliyetin öncülerinden biri Celal Nuri Bey’dir. Ona göre kadın meselesi hususi değil, tüm toplumu ilgilendiren bir meseleydi. Dolayısıyla geleneksel anlayıştan sıyrılarak kadınların iyi yetiştirilmesine gayret edilmesi toplumun sağlam temele oturmasında etkili olacaktı. Ona göre eğitim konusunda Amerika

20 Sebilürreşad, c. 17, S. 437-438, 21 Ağustos 1335 (1919), s. 171-173.

21 Sabiha Zekeriya, “Türk Feminizmi”, Вüyük Местиа, S. 4, 27 Mart 1335 (1919), s. 63.

22 Büyük Местиа, S. 6, 24 Nisan 1335 (1919), s. 89.

23 İstiklâl, S. 125, 28 Nisan 1335 (1919).

24 Z. S., "Kadınlık Şuunu”, Büyük Мecmua, S. 15, 13 Teşrîn-i Sânî 1335 (1919).

25 Büyük Местиа, S. 8, 28 Mayıs 1335 (1919), s. 128.

26 Galib Ata, "Hanımların Tip Tahsili", Вüyük Местиа, S. 12, 2 Teşrîn-i Evvel 1335 (1919), s. 189-190.

27 Selim Sırrı, "Doktor Hanımlar”, İstiklâl, S. 265, 1 Teşrîn-i Evvel 1335 (1919). 
örnek alınmalıyd1. ${ }^{28}$

Bu süreçte kadının sosyal ve ekonomik yaşamdaki durumu, eğitim ve kültür açısından neler yapabileceği, ailede ve çocuk eğitimindeki rolü ve görevi gibi konuları içeren bir anket düzenleyen Kadınlar Dünyası dergisi okuyucularına aşağıdaki soruları yöneltmişti:

"1. Kadınlarımız haklarını hangi vesaite müracaatle daha çabuk elde edebilirler?

2. Kadının ailedeki bugünkü vaziyeti hakkında düşünceleri nelerdir?

3. Kadınlarımız hangi mesleği seçmelidir?

4. Kadınların cemiyet hayatına iştirakleri hakkındaki fikirleri nelerdir?

5. Kadınlarımız çocuklarını nasıl terbiye etmelidir?

6. Kadınlarımız hangi kitapları okumalıdır?"

Ankete verilen cevaplarda kadınlara yapılan ayrımcılı̆̆ın terkedilmesi gerektiği ve erkeklerle eşit şartlar içerisinde yaşama hakkı tanınması yer aldı. ${ }^{29}$

\section{2. Çalışma Hayatında Kadın}

Osmanlı Devleti'nde art arda devam eden savaşlar ekonomik sorunları da beraberinde getirmişti. I. Dünya Savaşı'nın hemen öncesinde geçim kaygısı pek çok gencin evliliğe temkinli yaklaşmasının temel nedeniydi. Dolayısıyla yeni düzende kadının çalışması eşine destek olmasının yanı sıra kendi ihtiyaçlarını karşılayarak istediği yaşam konforuna ulaşması için de gerekli görülmeye başlandı. ${ }^{30}$ Kadınlara tahsis edilecek memuriyetler ve işler gazetelerde ilan edilmeli; hastanelerde, mekteplerde, ticarethanelerde kadınlara iş verilmeliydi. ${ }^{31}$ Fatma Aliye Hanım'a göre posta, telefon gibi kurumlarda kadınların istihdamı terakkiye doğru bir adımdı. Aynı zamanda Balkan Savaşları öncesinde yeniden teşkilatlanan Hilal-i Ahmer Cemiyeti Kadınlar Kolunun hastabakıcılar yetiştirmesi önemli merhalelerdendi. ${ }^{32}$

Kadınların sosyal hayatta yer almalarının bazı çevrelerde yarattığı rahatsızlık karşısında sorunlarının dile getirilmesinin zararı olmadığını ifade eden kadınlar; "Hiçbir vakit çarşaflarımızı yırtıp, başlarımıza şapkalar geçirerek sokaklara dökülmek, balolara iştirak etmek, açılmak, saçılmak istediğimiz yok. Bunlar hatırlarımızdan bile geçmiyor. Biz bundan Allah azimüşane sığınırız. Bizim, biz Osmanlı Müslüman kadınlarının bu istenilmeyen vadilere dökülmeden pek ve pek çok dertlerimiz vardır. Mesele çarşaf, peçe meselesi değil, belki asıl "kadınlık" meselesi olmalıdır." diyerek meselenin doğru anlaşılmasını istiyorlardı. Bu düşünceye göre olağanüstü şartlar gereği tüm ülkede ekonomik durum kötüydü. Savaşa katılmış olan diğer ülkelerde de mevcut olan ekonomik zorluklarla mücadelede kadınlar da destek oluyorlardı. Türk kadını da erkeklere destek olmalıydı. Savaşın ortaya çıkardığı kimsesiz aileler ve dul kadınların, ayrıca

\footnotetext{
28 Uyanık, a.g.m., s. 149-150.

29 “Hemşilerimiz Ne Düşünüyorlar?”, Kadınlar Dünyası, S. 194/4, 22 Ocak 1921, s. 13.

30 Kadinlar Dünyast, S. 144, 23 May1s 1330 (5 Haziran 1914), s. 9-10.

31 Ulviye Mevlan, "Kadınlar İş Bekliyor”, Kadınlar Dünyası, S. 157, s. 2.

32 Fatma Aliye, "Kadınlar Hakkında", Servet-i Fünûn, c. 50, S. 1289, 18 Şubat 1331( 4 Mart 1916), s. 178179.
} 
geçim zorlukları nedeniyle evlenemeyen erkeklerin durumu düzeltilmeliydi. Aksi takdirde ileride sosyal ve ahlaki felaketler ortaya çıkacaktı. Başka milletlere benzemeden kendi milletinin çizdiği sınırlar çerçevesinde çare aranmalıydı. Özellikle kadın doktorlar yetiştirilmeliydi. ${ }^{33} \mathrm{Bu}$ tarz görüşler taşradan da onay görüyordu. İslam Mecmuası'na Batum'dan bir mektup gönderen Trabzonlu Hacı Kamil Efendi kadınların ekonomik hayatın içinde yer almasını onaylamakla birlikte İslam kuralları çerçevesinde olmasının altını çizmekteydi. Derginin aynı sayısında yayımlanan ve İslam dininin konuya bakış açısının irdelendiği bir başka yazıda İslam'ın kadın ve erkeğe eşit yaklaştı̆ıından çalışma hayatında, özellikle de ticarette kadınların aktif olduğuna dair örnekler sunulmuştu. Ayrıca tıp alanında çalışmalar yapan kadınlar bulunduğu gibi savaşlarda askerlere su dağıtan gönüllü kadınların mevcudiyetine dair örnekler ile İslam'da kadının sosyal ve ekonomik hayatta erkekler ile aynı saflarda yer aldığına dair hadis ve rivayetlere yer verilmiş̧i. ${ }^{34}$

Savaş nedeniyle pek çok iş sahasının boş kalması üretim açısından kadınların da katkı sunmasına, bununla birlikte geçim kaygısına düşen kadınların sosyal statüsünde de değişime yol açmıştı. Savaş sürecinde çeşitli ülkelerde de ortaya çıkan cemiyetlerden biri Kadınları Çalıştırma Cemiyeti İslamiyesi adıyla İstanbul'da kuruldu. ${ }^{35}$ Cemiyetin üyeleri arasında hiçbir kadının bulunmaması eleştirilmekle birlikte "kadınlara iş bulup kendilerini namuskarane temin-i maişete alıştırarak himaye etmek" amacıyla faaliyetler yürütmeyi amaçlamış olması önemli bir yenilikti. ${ }^{36}$ Cemiyetin faaliyetlerinden biri kadınların gönüllü olarak askere alınması konusunda sağladığı destekti. 18-30 yaş arasındaki güçlü-kuvvetli Osmanlı uyruğu kadınlarından namuslu ve iffetli olduğunu mahalli mercilere tasdik ettirenlerin ve kucakta çocuğu bulunmayanların askerde geri hizmete alınması sağlanmıştı. Bununla birlikte savaşın sonunda cemiyetin kapanması söz konusu olduğunda Alemdar gazetesinde bu durumu eleştiren Refi Cevad Bey cemiyetin ittihatçı olmakla birlikte kadınların haklarını savunmak adına önemli bir iş yaptı̆̆ını belirterek bir ülkedeki kadınların konumunu ilerlemenin ölçüsü olarak değerlendirmişti. ${ }^{37}$

西

F. N., “Müracaat Ediyorum”, İslam Mecmuası, S. 2, Kânûn-1 Sânî 1330 (1915), s. 61-63.

İslam Mecmuası, S. 4, Kânûn-1 Sânî 1330 (1915), s. 114-115.

Enver Paşa'nın eşi Naciye Sultan'ın himayelerinde kurulan ve üyeleri arasında Enver Paşa dahil olmak üzere bazı devlet adamı ve ileri gelenlerin de bulunduğu cemiyet İstanbul merkez olmak üzere Osmanlı Devleti'nin diğer şehirlerinde de şubeler açmayı hedeflemiştir. Başlangıçta İstanbul'da üç bölgede (İstanbul, Üsküdar, Beyoğlu) 10'ar bin kişilik atölyeler açarak kadınların istihdamını hedeflemişti. Bu iş yerlerinde dantel, beyaz iş, elbise, makine ile çorap, fanila örücülüğü, asker çamaşırları, kostüm vs. ince işler gibi bölümler oluşturularak imal edilecek ürünlerin çarşı ve diğer mahallerde satılması planlanmıştı. İktisadiyat Mecmuası, c. 1, S. 23, 10 Ağustos 1332 (1917).

36 Kadınlar Dünyası, S. 194, 22 Kânûn-1 Sânî 1337 (1921), s. 6

37 Refi Cevad, "Kadınlarımız", Alemdar, S. 1568, 10 Eylül 1335 (1919). Uzun savaş yılları ekonomik ve siyasi pek çok sıkıntıyı ortaya çıkarmış, doğal olarak toplumsal yapıda da çözülmeleri getirmişti. Aile yapısından kadının yaşantısına kadar kendisini gösteren ekonomik ve toplumsal çöküntüyü hafifletmek yine kadınların üstlendiği vazifelerle giderilmeye çalışıldı. Kadınlar savaş yıllarında çeşitli örgütlenmeler içinde yer aldılar. Yardım dernekleri kurarak Türk insanının yaralarını sarmak üzere fedakârlıklarda bulundular. Savaş yıllarında kurulan bu cemiyetlerden biri 1915 yılının hemen başında oluşturulan Asker Ailelerine Yardımcı Hanımlar Heyeti'dir. Osmanlı ve Alman hanımları tarafından kurulan cemiyetin başkanları İstanbul Polis Şefi İsmail Canbolat Bey'in eşi Nuriye Hanım ve Liman Von Sanders'in kızı Nelly Hanım'dı. Servet-i Fünûn, 15 Kânûn-1 Sânî 1330 (28 Ocak 1915), c. 48, S. 1234, s. 179. Cemiyetin faaliyetleri ile ilgili ayrıntılı bir çalışma için bk. Nicole A.N.M. van Os, "Aiding the Poor Soldiers' Families: The Asker Ailelerine Yardımcı Hanımlar Cemiyeti”, Türkiyat Mecmuası, c. 21, (Güz 2011), s. 255-289. Asker Ailelerine Yardım Cemiyeti 1915 yılının Ocak ayı sonuna kadar 721 aileye aynî yardımda bulundu. Bu yardımlarda yağ, pirinç, fasulye, tuz ve giyim eşyası dağıtıldı. İçtihad, S. 125, 
Türk kadınının üretici yönünü ortaya çıkarması dönemin basınında övgü ile bahsedilen geliş̧melerdendi. Bu kapsamda I. Dünya Savaşı yıllarında Biçki Yurdu'nun açılması memnuniyetle haber verilen bir gelişmeydi. Nitekim Haşim Nahid tarafından Donanma mecmuasında ele alınan bir yazıda belirtildiğine göre eskiden terzilik mesleğinde oldukça ileri olduğu halde II. Meşrutiyet yıllarına kadar batıdan etkilenen ve entari yerine ceket, etek gibi Batı kıyafetine itibar eden Türk kadını yabancı olduğu bu tarz giyim üretimlerini de yabancıların eline vermiş̧ti. II. Meşrutiyet ile birlikte bu alanda kendi cevherinin farkına varan Türk kadını Biçki Yurdu adlı kurumu oluşturdu. Savaş yıllarında diğer hayır cemiyetleri gibi kadına çeşitli desteklerde bulunan Biçki Yurdu önemli bir görev yüklenmişti. Şehit eşlerine ve kimsesiz hanımlara dantel öğreten bir sınıf da açan kurumdan beklenti de hayli yüksekti. Burada kadınların ihtiyaç duydukları elbiseleri bizzat dikme imkânını elde etmeleri ile oldukça kazançlı olan terziliğin ekonomik açıdan rahat bir hayat sürmeyi temin edeceği, ayrıca ekonomik özgürlüğü bulunmadığı için kadınların erkeklerin tahakkümüne maruz kalmasını önleyeceği gibi iki tarafın ilişkilerini makul ve insani bir şekle sokarak aile temelinin sağlam olmasına destek sağlayacağı düşünülüyordu. Ayrıca bir sanat bilmek akıl ve zekânın geliştiğini gösterir ki kadın zekâsının kullanıldığı bu tarz işler mutlak surette terakki sağlayacaktı. Yazar, eğitimin ekonomik durumun yeterli olması halinde gerçekleşebildiğini, dolayısıyla yalnızca erkeğin para kazanmasının kafi olmadığını, terzi hanımların çocuklarının eğitimine katkı sunarak memleketin irfanına da destek olacağını düşünmektedir. Bu faaliyetlerin kadınlara özgüven de kazandırdığını iddia eden yazara göre burada kendilerini ifade edip, fikir alışverişi yapabileceklerdi. Biçki Yurdu'ndan yetişecek terzilerin gerek öğretmenlikte gerekse Anadolu'nun çeşitli yerlerinde yapacakları girişimlerle bu sahadaki ecnebi hegemonyasını ortadan kaldırıp milli serveti arttıracaklarına da inanmaktaydı. Haşim Nahid Bey kadınlığın acınacak seviyesini yükselmeyi yine bir kadının düşünmüş olmasına da vurgu yaparak böyle yeniliklere gözlerini kapayan erkeklere ise ortaya çıan sonucu iyi değerlendirmelerini tavsiye etmişti. ${ }^{38}$

Savaş yıllarında diğer ülkelerde de kadının çalışma hayatındaki faaliyetleri gittikçe genişleyen bir hareket halini almıştı. Türk kadını da gerekli eğitimi alıp erkeklerle iş sahasında yarışacak duruma gelmişti. Kimi erkeklere göre "ekmek aslanın ağzında" sözü artık "ekmek kadının ağzında" şekline dönüşmüştü. Kadınlar iş hayatındaki bazı fırsatları da zamanla ele geçirmiş bu da ister istemez bir rekabet duygusunu ortaya çıkarmışt. ${ }^{39}$

Kadınlar Dünyası'ndaki yazısında Ulviye Mevlan Türk kadınının adeta sürünmek şeklinde yaşamını sürdürdüğünü, medeni milletlerin kadınları gibi ilerlemek, yükselmek ve mutlu olmak istediklerini ifade ediyordu. Dolayısıyla o, kadınların üzerindeki ataleti terk etmelerinin erkeklerle eşit haklara kavuşturularak toplumsal yaşama dahil olmasıyla sağlanabileceğini düşünüyordu. ${ }^{40}$

30 Kânûn-1 Sânî 1330 (12 Şubat 1915), s. 462. Savaşın cephe gerisinde oluşturduğu tahribatı önlemek adına cephede müttefiklik yapan toplumların kadınlarının birbirlerine desteği de dönemin en çarpıcı gelişmelerindendi. Nitekim Alman kadınları Alman veliahdının eşinin himayelerinde Berlin civarında bir tiyatroda müsamere düzenleyerek gelirlerini savaşta eşini, çocuğunu kaybeden Osmanlı kadınlarına dağıtmayı kararlaştırmıştı. Servet-i Fünûn, c. 50, S. 1294, 6 Nisan 1332 (19 Nisan 1916).

38 Haşim Nahid, “İktisadi Hadiseler”, Donanma, S. 69, 19 Teşrîn-i Sânî 1331 (1915), s. 1106. Biçki Yurdu gazete ilanları ile kadınların bu faaliyetlere katılmasını teşvik etmeye çalıştı. Tasvir-i Efkar, S. 1338, 19 Kânûn-1 Sânî 1331 (1 Şubat 1916).

39 Burhan Cahid, “Kadın Derdi- Post Kavgası”, Servet-i Fünûn, c. 54, S. 1382, 28 Şubat 1334 (1918), s. 54 55.

40 Ulviye Mevlan, “Düşünüyorum”, Kadınlar Dünyasl, S. 181, 6 Temmuz 1334 (1918), s. 2. 
Sabiha Zekeriya'ya göre ülkede pek çok alanda işgücü azalmıştı. Kadınlar bu boşluğu doldurarak toplum içinde hak ettikleri konuma gelebileceklerdi. ${ }^{41}$

Kadınların resmî dairelerde çalışması başlangıçta muhafazakârların tepkisiyle karşılanmıştı. Gişelerde görevli kadınlar bazı tutucu erkeklerin kızgın bakışlarına maruz kalmışlarsa da aradan geçen yıllar ve koşullar kadınların bu sahadaki görünürlügüüne erkeklerin alışmasını sağlamış, hatta bu bakışlar daha munis ve hürmetkar olmuştu. Çünkü kadınların geçim kaygısı ile iş hayatına girmek zorunda kalması, hatta erkek kıyafetleriyle çaycılık gibi işleri yapmaya başlaması her Müslümanın ruhunu sızlatan görüntüler olarak telakki edildi. Bununla birlikte İslamcılar kadının iş sahasına girmesini "anarşi”" olarak görmeye devam etti. Türk toplumunda kadının çalışma hayatında erkekle bir arada olmasına taraftar olan erkekler Milli Mücadele yıllarında dahi enderdi. Kimilerine göre kadınlar iki sebeple iş hayatına dâhil olmuştu: Geçim derdi ve evlilik. Bu görüşe göre kadınların aldıkları ücretler ulaşım masrafları çıktıktan sonra karın doyuracak derecede bile değildi. Ayrıca memur olarak çalışan kadınların büyük kısmı bekâr genç kızlardı ve bunların özellikle parklarda, açık alanlarda, sokaklarda dolaşması, erkeklerle bakışmaları ahlaki yönden yüz kızartıcıydı. Dolayısıyla "Bekarlığı ref edecek, Türk unsurunun iktisadi hastalıklarını süratle tedavi edecek olan esaslı ve milli teşkilattır." Kadın ve erkeğin bir arada çalışmasının artık önü alınamayacak derecedeydi. Ahlaki yozlaşmaya müsaade edilmeden çareler aranmalıydı, aksi takdirde sosyal yaşam tehlikeye girecekti. ${ }^{42}$

Yusuf Razi İstiklâl gazetesindeki yazısında kadınların iş hayatında yer almalarına rağmen negatif ayrımcılığa uğradığını, muadil iş yaptıkları erkeklere göre daha az ücret aldıklarını belirtiyordu. Ona göre Avrupa'da çalışan kadınlardan emzirenlere özel şartlar getirilmesi, hamilelik döneminde izin verilmesi gibi talepler dile getirilirken Türk toplumunda bu tarz taleplerin dillendirilmesi oldukça uzak görünüyordu. ${ }^{43}$

Kadınların çalışma hayatında yer alması iş ahlakına dair tartışmaları da ortaya çıkardı. Bu konuyu ele alan bir yazıda resmî dairelerde kadınların işlerini hakkıyla yapmadığı eleştirilerine yer verildi. Hatta bir ayrıma gidilerek kadınların kızlardan daha çalışkan, özenli ve dikkatli olduğu, bununla birlikte genç ve bekâr kızların devlet dairelerinde işlerini gereği gibi yapmadı ğı ileri sürüldü. Durumun mahzurlarının dile getirildiği bir yazıda kadınların erkek bulunmayan idarehanelerde daha verimli çalışacağ 1 iddia ediliyor, erkeklerden cesaretsiz ve tecrübesiz oldukları eleştirisine ilaveten "...Haram emvale el uzatmak ve vahdet-i milliyeye ihanet etmek hususunda kadınlarımız umumiyetle erkeklerimiz kadar mütereddi görünmüyor." ifadelerine yer verilerek resmî hayatta kusurlu kabiliyetler içinde oldukları ithamında bulunuluyordu. Buna mukabil erkekler gibi çay, kahve ve sigara içerek mesailerini aksatmak tarzında bir durumları olmaması ise olumlu yönleri olarak görülüyordu. Buradan hareketle resmî iş hayatını kadınlara terk etmek uygun değildi. Yazar kadınların aldığı maaşı da sorgulamış, 300-800 kuruş civarında maaş alan kadınlara mukabil erkek memurların vahim durumda olduğunu ve çoğunun borçlu olup cenazelerinin bile iane veya veresiye ile kaldırıldığını iddia etmişti. "Türk kadınlarını memuriyet hayatına ısındırmamak daha hayırlıdır." diyen yazar kadınların özel atölyelerde, iş evlerinde, terzilik, gömlekçilik, kolacılık, karavancılık,

41 Sabiha Zekeriya, “Kadınlara Çalışma Hakkı”, Büyük Мecmua, S. 11, 18 Eylül 1335 (1919), s. 170.

42 Safi, “Resmi Hayatta Türk Kadınları”, Servet-i Fünûn, c. 56, S. 1456, 20 Mayıs 1336 (1920), s. 305.

43 Yusuf Razi, “ Harpten Sonra Kadınlar”, İstiklâl, S. 105, 8 Nisan 1335 (1919). 
oyacılık gibi imalat işleri ile meşgul olmalarının daha uygun olacağı değerlendirmesini yapmıştı. ${ }^{44}$

Milli Mücadele yıllarında yayımlanan Diyane dergisinde kadının batıda elde ettiği haklar ve yaşam tarzı ile erkeklerle rekabet eder hale gelmesi olağanüstü koşulların sağladığı olumlu katkılar olarak değerlendirilirken Türk kadınına da bu yönde firsatlar verilerek sosyal ve kültürel hayatta üstün bir konuma yerleştirilmesi sağlanmalıydı ${ }^{45}$ Dönemin kadın hakları savunucuları da bu yönde düşüncelerini okuyucuyla paylaştı. Yazarlara göre kadının çalışması dönemin şartları açısından ülkenin ayağa kalkabilmesi için şarttı. Kadın çalışarak hem üretken olacak, hem de geçim mücadelesinde eşine destek olacaktı. Bununla birlikte dönemin aydınlarına göre Anadolu köylerinde kadınlar zaten üretici kimliğinin farkındaydı. Şehirli kadınların da bu bilince sahip olması gerekliydi. Böylelikle moda ve süs iptilası karşısında gereksiz harcama yapmaları önlenecek, tüketicilikten üretici duruma geçeceklerdi. ${ }^{46}$

\section{Toplum ve Ailede Kadın}

Dönemin kimi yazarına göre kadınlar dayanılmaz bir esaret ve hakirlik içinde inlemekteydi. Kadınlığın bu sefaleti devam ettikçe de istenen ilerleme sağlanamayacaktı. Bu çöküşün nedeni ise kadınların sosyal hayatta yer almaktan mahrum bırakılmasıydı ${ }^{47}$ Diğer bir görüşe göre ise kadınlar her türlü saadet ve hürriyete sahipti. Bununla birlikte asıl mesele kadına verilen hakların bazı kesimlerce uygulanmamasıydı. Hal böyleyken bu durum toplumun geneline mal edilerek baskı ve zulüm altında tutuldukları iddia edilemezdi. ${ }^{48}$

Kadın meselesinin toplumun en önemli ve çözüm gerektiren meselelerinden biri olduğu düşüncesi kimi yazarlar tarafından dile getirilerek öncelikle vatan mefhumuna karşı ifaya mecbur olunan vazifelerden başlanarak kadın ve erkeğin vazifelerinde ayrıldığı ve en önemli noktanın bu olduğu belirtilmişti. Erkek serhade giderken kadın beşik başındadır. Dolayısıyla ikisi ayrı ama bir milleti ayakta tutan kutsal görevlerdedir. Kadın yaradılışı gereği savaşta, cephede yer alacak dirence sahip olmadığı için ancak cephe gerisinde hastabakıcılık gibi yine insan hayatını kurtaracak, neslin devamını sağlamaya gayret edecek görevleri ifa edebilir. Dolayısıyla vatanın kadından beklediği en büyük yardım ve destek evlat yetiştirmektir. ${ }^{49}$

Gelenekçilerin kadının toplumsal konumu ile ilgili anlayışı bu noktada yenilikçilerle örtüşüyordu. Sebilürreşad dergisinde "Kadın Bir Valide Olmaya Gayret Etmelidir" başlığıyla yayımlanan bir yazıda kadının asli görevinin aile hayatını idame ettirmek olduğu fikri savunularak erkeğin dışarda, kadının içerde çalışarak eşitliği sağladığı ifade edildi. Kadının dışarda çalışması

44 Safi, “Resmi Hayatta Türk Kadınları”, Servet-i Fünûn, c. 56, Sayı. 1458, 17 Haziran 1336 (1920), s. 17.

45 Ümüt Akagündüz, "1918-1928 Yılları Arasında Yayımlanan Kısa Ömürlü Osmanlıca Kadın Dergileri Hakkında Bir Değerlendirme", Kebikeç, 34, 2012, s. 333.

46 Çilem Tuğba Akdağ, Kadın Dergilerinde Kadın Modernleşmesi (1869-1927), Yayımlanmamış Doktora Tezi, Erciyes Üniversitesi Sosyal Bilimler Enstitüsü, Kayseri 2015, s. 196-198.

47 Osmanlı toplumunda kadının ihmal edildiği görüşü dönemin aydınlarından Celal Nuri tarafından da dile getirilmişti. Uyanık, a.g.m., s. 141.

48 Orhan Mithad, “Kadınlarımız Hür mü? Esir mi?”, Musavver-i Malumat-ı Nafia, S. 8, 3 Nisan 1330 (16 Nisan 1914)

49 Selahaddin Asım, "Kadın ve Harp”, İçtihad, S. 125, 30 Kânûn-1 Sânî 1330 (12 Şubat 1915), s. 463-464; Abdülfeyyaz Tevfik, "Kadın ve Vazife”, Servet-i Fünûn, c. 56, S. 1439, 11 Kânûn-1 Evvel 1335 (1919), s. 98-99. 
ilerleme yerine gerileme sağlayacaktı. Annelik üzerinden yapılan değerlendirme ile çalışma hayatına dahil olanların çocuğunun gıdasını engelleyeceği iddiası dahi ortaya atılmıştı. Nitekim yazara göre annenin en önemli ve en zor işi çocuğunu terbiye etmekti. İyi yetişmiş nesillerden memleketi kurtaracak kahramanlar çıkabileceği düşüncesiyle "Valide bilmelidir ki salladığı adi bir salıncak değil mehd-i (beşik) beşeriyettir. " uyarısında bulunulmuştu. ${ }^{50}$

Milletlerin sosyal ve siyasi hayatındaki gerileme ve çöküşlerinde kadının rolü önemliydi. Toplumu oluşturan fertler dini ve milli terbiyeyi ilk olarak anne şefkatinden almakta, vatanperverlik, istikamet, fedakarlık, diğerkamlık gibi kavramlar kadınlar tarafından öğretilmekteydi: "İrfanlı bir ana terbiyesi en mükemmel mekteplerin, en muktedir mürebbilerin muvaffak olamadıkları harikaları ibda edebilir. Kadın yalnız evladını değil, zevcini, kardeşini, hatta pederini hayatın sarsıntılarına karşı şefkatkar tesellilerle teçhiz eden bir meleke-i siyanettir.” Bu nedenle toplum içinde kadın hiçbir şekilde ihmal edilmemeliydi. Yazara göre ilk defa İslam dini kadına yüksek bir mevki kazandırmış, aynı zamanda ona bazı görevler yüklemişti. Bununla birlikte son yıllarda yanlış adımlar atılması kadınlığın yükselmesine değil çöküşüne sebep olmuştu. Yazar ahlaki çöküntünün artması ve bazı kadınların fuhuşa sürüklenmesini batı medeniyetinin koyu bir taklitçilikle benimsenmesine bağlamıştı. Hatta burada moda istilası en etkili unsurdu. Nitekim "taklitçilik milletlerin benliğini kaybedip, yıkılışlarına yol açmaktaydı." Yazara göre iradesi zayıf insanlar gayri meşru yollara girebilir. Bu nedenle bazı kadınları sukut ettiren etken de ekonomik nedenler değil, ihtiras taşkınlıklarıydı. Kadınların bu yanlış yoldan döndürülmesi görevi de yine aydın İslam kadınlarına düşüyordu. Bu amaçla bazı kadınlar bir cemiyet teşkiline karar vermişti. ${ }^{51}$ Kimi yazara göre ise Osmanlı toplumunda Avrupa kadınları ve yaşam tarzları ile ilgili önyargı geliştirilmişti. Oysa Paris'in kadını hiç de İstanbul'dan göründüğü gibi sadece süslenmekle uğraşmıyor, ev işleri ve çocuk bakımı da yapıyor hatta resmî kurumlarda çalışıyordu..$^{52}$ Dönemin kadın yazarlarına göre Türk kadınları da geleneksel görevlerini yerine getirmekle birlikte aynı zamanda modernleşebilirdi. Türk kadını gerektiğinde ev idaresinden anlar, mutfağa girip aşçı gibi mükemmel yemekler pişirebilir, bunun yanı sıra iyi derecede yabancı dil de konuşabilirdi. ${ }^{53}$ Ruşen Eşref Bey İstiklâl gazetesinde yazdığı bir yazısında Türk milletinin aydınlanması için annenin önemini vurgulamıştı. ${ }^{54}$ Milli Mücadele yıllarında farklı bakış açılarından yaklaşsalar da dönemin aydınlarına göre annelik kadının en ulvi vazifesiydi. ${ }^{55}$

Sebilürreşad, c. 21, S. 534-535, 9 Haziran 1339 (1923).

Sebilürreşad, c. 17, S. 429-430, 17 Temmuz 1335 (1919), s. 104-106.

Akagündüz, “ 1908- 1918 Yılları Arasında...”, s. 336.

Akdağ, a.g.t., s. 173-175.

Ruşen Eşref, “Ana”, İstiklâl, S. 172, 14 Haziran 1335 (1919).

Akdağ, a.g.t., s. 180-181. Ülkenin içinde bulunduğu durum dolayısıyla milli meselelerin daha da önemsenerek fertlerin iyi birer vatandaş olması için aile içindeki eğitim ve dolayısıyla kadına düşen görevin ön plana çıkarılması gerektiğini düşünen kesim, kadınların erkeklerle aynı fikri kudrette bulunduğunu, istedikleri her şeyi öğrenip eğitimin en yüksek aşamalarına kadar yükselme haklarına sahip oldukları belirtiyordu. Kadınların milli vicdana borçlu oldukları mukaddes görevi, milli duyguları hakim kılacak tarzda nesiller yetiştirmekti. Bundan hareketle kadının en temiz lehçe ile dili, hurafeden arınmış dini, atalarını tanıtan ve sevdiren tarzda tarihi ve gelenek görenekleri, çocuk terbiyesi ve sağlık gibi konuları öğrenmeleri gerekiyordu. Abdülfeyyaz Tevfik, "Kadın ve Vicdan”, Servet-i Fünûn, c. 56, S. 1437, 27 Teşrîn-i Sânî 1335 (1919). 
Kadının annelik görevini gerektiği gibi yerine getirmesinin şart olduğu ifade edilen bir başka yazıda bu görevin hamilelik sürecinde başladığına dikkat çekilmişti. Yazıda bazı kadınların hamilelik döneminde süslenmek veya güzel görünmek adına giyimine ve sağlığına dikkat etmemesi eleştirilmişti. Yazar yüksek ökçe ve uygun olmayan kıyafetler giyilmesinin bebeklerinin sağlığını olumsuz etkilediğini vurgulayıp kadınların ev, meslek ve dünya kadını gibi sınıflamalardan birini tercih etmesi gerektiği düşüncesindeydi. Son yıllarda özellikle dünya kadını sınıflamasına giren pek çok kadının yaşayış tarzı aileler arasında taklit edilmekte ve günden güne bir yara olmaktadır. Herkes özel hayatında özgür olmakla birlikte toplumu ilgilendiren meselelerde hareketlerinden mesuldü. Anne olan bir kadın zevkinden feragat etmeliydi. Oysa bazı kadınlar çocuğunu sütnine ve dadılara bırakarak kendi vereceği terbiyeden mahrum etmeye başlamıştı. Aynı şekilde fakir tabaka kadınları da çocuklarına gerektiği gibi bakamıyordu. Yazar bu meseleye çözüm olarak ülke içinde ırzahane (emzirme evi) ve veladethane (doğumevi) sayısının arttırılmasını öneriyor, kadının iş hayatına dâhil oluşu ile birlikte çocuklarının bakım ve eğitimi için devlet makamlarının da destek olmasını ve gerekli müesseselerin oluşturulmasını umuyordu. Diğer yandan aileden, anneden bu kadar uzak büyüyen çocukların aile bağı kurmakta zorlanabileceğine dair endişe ise çocuk bakımı ve eğitimi bilmeyen bir annenin elinde büyüyen çocukların çok daha fazla zarar göreceği tespiti ile açıklanıyordu. İyi eğitim görmüş, dadı, sütnine ve mürebbilere ihtiyaç olduğunu dile getiren yazara göre; "Her yerden ziyade bizim yurdun çocukları anasız, himayesiz, talak sevkiyle büyür. Bizim memleketin çocukları sıhhat ve kuvvetten mahrum oldukları gibi dini, milli, her türlü terbiyeden de mahrumdur." ${ }^{\circ 6}$ Başka bir yazara göre çocuk yetiştirme geleneksel eğitim tarzında olmamalı; anneler çocuklarını hurafelerle, batıl inançlarla değil milli benliğe sadık kalarak bilimsel bilgilerle, çağın gereklerine göre eğitmeliydi. ${ }^{57}$

Kimilerine göre esasen eski Türk devletlerinde, hatta İslamiyet'ten sonra dahi kadınlar sosyal, ekonomik faaliyetlerde, eğitim hayatı içinde aktif yer alırken zamanla kapalı ortam dışına çıkmayan kadının kamuda görünür olması muhafazakâr çevrelerde rahatsızlık yaratmıştı. Oysa "Şeriat kadını alçaltıcı hiçbir emri ihtiva etmez. Şeriat nazarında kadın sosyal hayattan hariç değildir." ${ }^{58}$ Muhafazakârlara göre ise kadının bazı vasıfları erkekten aşağı olduğu için erkeğin emri ve hakimiyeti altında yaşamalıydı. Kadının bedenen erkekten daha zayıf, idraken daha geri olduğunu ve erkekle eşit seviyeye gelemeyeceğini savunan gelenekçiler arasında yazar, fikir adamı ve mebuslar da bulunuyordu. ${ }^{59}$ Nitekim Meclis-i Mebusan oturumlarında da kadının bedenen ve fikren erkekten geri olduğunu düşünen mebuslar Pasaport Kanunu sırasında bu düşüncelerini dile getirmişlerdi. ${ }^{60}$ Hüseyin Ragıp Yeni Mecmua'da yer alan bir yazısında kadının bedenen ve

56 Sabiha Zekeriya, “Süt Nine ve Dadı Mektebi”, Büyük Mecmua, S. 8, 28 Mayıs 1335 (1919), s. 127.

57 Mefkure, S. 7, 16 Haziran 1335 (1919).

58 Kazım Nami, “Kadınlık İçin”, Donanma, S. 77, 28 Kânûn-1 Sânî 1331 (10 Şubat 1916).

59 Kadının yaradılış itibariyle erkekten geri olduğunu savunanlara göre bu tespit tarihin çeşitli dönemlerinde filozoflar tarafından da dile getirilmiştir. Maruf Er-Rusafi (Müntefik Mebusu), Erkekle Kadın Arasında Müsavat Olabilir mi?, Evkaf Matbaası, İstanbul 1333.

60 Hüseyin Ragıp, "Hayat Mücadelesinde Kadın”, Yeni Mecmua, S. 39, 11 Nisan 1334 (1918), s. 242. 1917 yılı içinde Meclis-i Mebusan müzakerelerinde kanun ile ilgili görüş bildiren Zor mebusu Mehmed Nuri Efendi bir kadının, eşinin izni olmadan değil yabancı ülkeye seyahat etmesinin evinden dahi dışarı çıkmasının dinen caiz olmadığını iddia etmişti. Meclis-i Mebusan 3. Dönem Tutanak Dergisi, C. 0001, 13. Birleşim, 3 Kânûn-1 Evvel 1333 (1917), s. 181-182. Pasaport kanunu ile ilgili yapılan müzakerelerde bir kadının Avrupa'ya seyahatinde eşinin izninin olması gerektiği yönündeki görüş taraftar bulduğu gibi bu durumu eleştiren ve kabul etmeyen mebuslar da düşüncelerini ifade etmişlerdi. Meclis-i Mebusan 3. 
fikren erkekten geri, duygu açısından daha hassas olduğunu iddia edenlerin dayandığı temeller arasında kadınların bedensel olarak bazı işleri yapmasının imkansız olduğunu dile getirmelerini eleştiriyordu. Oysa Anadolu'da tarla sürmek, hasır işlemek, harman savurmak, yün taşımak gibi güç gerektiren işler kadınlar tarafından yapılmaktaydı. Ayrıca şehirlerde, fabrikalarda en ağır işleri yapan kadın işçiler vardı. Anadolu kadını tarlada, bahçede erkeği ile çalıştıktan sonra akşam ev işleriyle de ilgileniyordu. Dolayısıyla kadın, bedenen erkekten daha fazla çalışıp dayanıklılığını gösteriyordu. Kadınlar erkeklerden daha uzun yaşayarak da erkekten geri bir bedeni yapıya sahip olmadığını ispat ediyordu. Kadınların evlerde veya kapalı ortamlarda kalmaları onların ruh sağlığını olumsuz etkileyerek bazı ruhsal bozukluklara neden oluyordu. Ĕger sosyal ve ekonomik yaşama dâhil olurlarsa bu problemleri kalmayacaktı. Evliliğin kadının ömrünü törpülediği iddia edilen yazıda eğer evlilikte kadın ve erkeğin konumu yakın olursa bu olumsuzluk da ortadan kalkacaktı. ${ }^{61}$

Bazı kadın yazarlara göre kadınların içinde bulunduğu geri kalmışlıktan erkekler kadar kadınlar da sorumluydu. ${ }^{62}$ Fakat burada sorunun kaynağı, yetiştirilme şartları ve toplumun kadın ve erkeğe biçtiği rollerin yine kadın vasıtasıyla nesilden nesil aktarılmasıydı. Geleneksel yetiştirilme tarzı kadını eğitim hayatından ve sosyal yaşamdan geri bırakarak bilinçli olmasını da engellemişti. Hatta kimi kadınlar "Kadın Nedir?" sorusuna "Saçı uzun aklı kısa bir mahlûk." şeklinde cevap verebilecek kadar buna inanmıştı. ${ }^{63}$

Kadının kamudaki varlığının bazı çevrelerde yarattı̆̆ı rahatsızlığa rağmen 19. yüzyılın ortalarından itibaren değişim ve dönüşümün kadını ve hayatını şekillendirmesi ve 20. yüzyılın başında ortaya çıkan olağanüstü koşulların da tetiklemesiyle hızlı bir zihniyet değişimi de oluşturduğu muhakkaktı. Nitekim Tanzimat'ın ilk yıllarında erkeklere mektup yazarlar endişesiyle kızlarını okula göndermek istemeyen babaların zihniyeti değişmişti. II. Meşrutiyet yıllarında binlerce kız eğitim hakkını kullanmıştı. Dolayısıyla kadının erkekten geri olduğu ve onun tahakkümünde kalması gerektiği anlayışı da zamanla değişecek algılardan biri olarak görülüyordu. ${ }^{64}$

Bu yıllarda Osmanlı aile kurumunu düzenleyen oldukça cesur bir kanun 1917 yılında, henüz savaş devam ederken çıkarıldı. Geniş ailelerin yerini çekirdek ailelerin almaya başladığı bu süreçte 25 Ekim 1917 tarihinde yürürlüğe konan Hukuk-1 Aile Kararnamesi İttihat ve Terakki yönetiminin

Dönem Tutanak Dergisi, Cilt: 0001, 6. Birleşim, 24 Teşrîn-i Evvel 1334 (1918), s. $52-53$.

61 Hüseyin Ragıp, “Hayat Mücadelesinde Kadın”, Yeni Местиa, S. 39, 11 Nisan 1334 (1918), s. 243. Nüfus azaldığı için kadının zevcelik görevini ihmal etmemesi gerektiğini düşünen Celal Nuri görücülüğe karşıdır. Ona göre evliliklerin uzun ömürlü olması için eşler eğitim ve kültür açısından birbirine yakın olmalıdır. Uyanık, a.g.m., s. 150; Akdă̆, a.g.t., s. 183. Bir görüşe göre mutlu bir aile yuvası oluşturmanın püf noktalarından biri de kadının sohbeti bilmesiydi. Musavver Malumat-ı Nafia, S. 19, 19 Haziran 1330 (2 Temmuz 1914), s. 299; Türk Kadını, S. 1, 23 Mayıs 1334 (1918).

62 Selahaddin Asım, "Kadın Gibi”, İçtihad, S. 124, 1 Kânûn-1 Sânî 1330 (14 Ocak 1915), s. 436-438.

63 Bint-i Pertev Hediye, “Kadınlığın İtilası”, Kadınlar Dünyası, S. 175, 25 Mayıs 1334 (1918), s. 6-8.

64 Hüseyin Ragıp, "Hayat Mücadelesinde Kadın”, Yeni Местиa, S. 39, 11 Nisan 1334 (1918), s. 242. Kadınların hak mücadelesi ve kamuda daha fazla yer alması kadın erkek mücadelesinin her açıdan irdelenmesi sonucunu doğurmuştu. Bu konulardan biri kadın ve erkeğin görev ve sorumluluklarının tarihçesini anlatan yazılardı. Bu tarz yazılarda tarihin ilk devirlerinde her cinsin kendi vaziyetinden memnun olduğu, mücadelenin medeniyet devrinde ortaya çıktığı sonucuna varılmıştı. Bu konuda yayımlanan bir yazıya göre eski sükûnetin de bugünkü istical ve feveranın da doğru olmadığı, kadın erkek davasının yeniden tetkik edilerek, fikri farklar ve kabiliyetler dikkate alınıp yeni ve makul bir görev paylaşımı ve düzen oluşturulması gerekliydi. Servet-i Fünûn, c. 56, S. 1435, 13 Teşrîn-i Sânî 1335 (1919); A. K., "Kadın, Tip ve Biyoloji”, Mefkure, S. 10, 7 Temmuz 1335 (1919), s. 3-4. 
getirdiği en radikal değişikliklerdendi. Kararname ile evlenme akdine devletin müdahalesi söz konusu olmuş, çok eşlilikte ilk eşin onayı aranmış ve bu anlamda çok eşlilik daraltılmıştı. Kanunla evlenme yaşı kadınlarda 17, erkeklerde 18 olarak belirlendi. Çeşitli durumlarda kadına da boşanma hakkı tanındı. Ayrıca Müslüman olmayanların evlenme ve boşanmaları düzenlenmiş ve boşanma için aile meclisi kurularak karar verilmesi öngörülmüştü. Sabiha Zekeriya kararnameyi kadınlık hayatında ortaya çıkan "terakki ve tekamülün diğer bir tecellisi" olarak görüyordu. Ona göre "Düne kadar ailede dun mevkiinde tutulan ve erkek karşısında hiçbir hakka sahip olmayan kadın, bu kararname ile az çok müsavi bir vaziyete getiriliyor. Ailede ona da bir mevki veriliyordu." Bununla birlikte kanunun uygulanmasında az çok tadile ihtiyacı olduğunu düşünen Sabiha Zekeriya böylesi bir tadilatta kanunun ruhuna dokunulmasından da endişeliydi. ${ }^{65}$

Kadınların haklar elde etmesi ve feminizmin Türk kadınları arasında yaygınlaşması bazı aydınlara göre taklitçilikten başka bir şey değildi. Nitekim Doğu ve Batı medeniyeti arasında hak mücadelesine konu teşkil eden meseleler farklıydı. Batıda feminizm erkeklerin zulüm ve tahakkümünden ziyade açlık ve sefalet altında inleyen kadınların sızlanmasının bir sonucu olarak ortaya çıkmıştı. Oysa Türk toplumunda kadınla erkek arasında büyük bir fark yoktu. Bununla birlikte eksiklik yalnızca kadınlık konusunda değildi ve sslahat topyekûn bir değişimle olabilirdi. $\mathrm{Bu}$ amaçla fert ve aileden başlamak gerekliydi. Kadının mekteplerde göreceği tahsil ıslahat için tek başına yeterli değildi: Hars ıslah edilmedikçe, milli terbiyenin şekli takarrür etmedikçe okuyan, yüksek tahsil gören her genç kız bir "Madam Bovary" olma tehlikesinden kurtulamazd1. ${ }^{66}$ Milli Mücadele yıllarında da bu konuda benzer tespitler yapılmıştı. Rauf Ahmed Bey'e göre Doğu ve Batı medeniyetinin toplumsal koşulları farklıydı. Batı'da feminizm tartışmaları kadının çalışma ve sosyal yaşamın içine dâhil edilmesi ekseninde sürdürülürken doğuda tesettür gibi şekli unsurlara takılmıştı. Oysa kadının siyasi ve ekonomik konumu değiştirilmeliydi. ${ }^{67}$

$\mathrm{Bu}$ süreçte kadın meselesi konusunda konferanslar da düzenlendi. İzmirli İsmail Hakkı Bey tarafından Darülfünun'da verilen İslam'da Kadının Hukuku ve Vezaifi konulu konferansta bir milletin erkek ile terakki sağladığı fakat bu terakkinin kadın tarafından ikmal edildiği belirtilmişti. İsmail Beye göre "Kadın mader-i alimdir: Her millet terbiye-i esasiyesini ana kucağında öğrenir. Kadın muallim-i âlimdir: Her millet medeniyetin ilk dersini anadan öğrenir. Kadın istikbalin sahibidir: Her cemiyetin saadet-i hakikiyesi hüsn-i terbiye görmüş faziletli kadınların elindedir." $\mathrm{O}$, kadınların eğitim ihtiyacını karşılaması, asra uygun yetişmesi konusunda herkesin hemfikir olduğunu fakat bunun için iki yolun takip edilebileceğini belirtmişti: Birinci yol Batı medeniyetinin ortaya çıkardığı terbiye, diğeri ise İslam'ın tebliğ ettiği terbiyedir. Batı tarzı terbiye "hariçten gelen beşeri bir çare”, ikincisi ise "dahilde bulunan ilahi bir çareydi." Ona göre beşeri çare kesin

65 Sabiha Zekeriya, Türk Kadınlığının Terakkisi”, Büyük Мecmua, S. 1, 6 Mart 1335 (1919). Kararname, savaş sona erip İttihat ve Terakki yönetimi iktidardan düşünce uygulamadan memnun olmayan kesimlerin -özellikle gayrimüslimlerin- etkisiyle ve işgal güçlerinin baskısıyla Damat Ferit Paşa Hükümeti döneminde yürürlükten kaldırıldı. Toprak, a.g.e, s. 13; Zihnioğlu, a.g.e., s. 51-52; Kurnaz, a.g.e., s. 6061; Mehmet Akif Aydın, "Hukuk-1 Aile Kararnamesi", Diyanet Vakfi İslam Ansiklopedisi, C. 18, İstanbul 1998, s. 314-318. Hukuk-1 Aile Kararnamesi ile çeşitli değerlendirmeler için bk. Orhan Çeker, "Hukuk-1 Aile Kararnamesi Giriş ve Tarihçesi", Mehir, İlkbahar 1999, s.19-21; Abdurrahman Yazıcı, "Osmanlı Hukuk-1 Aile Kararnamesi (1917) ve Sadreddin Efendi’nin Eleştirileri”, Ekev Akademi Dergisi, S. 62, Bahar 2005, s. 567-584.

66 Ocak, S. 3, 30 Kânûn-1 Sânî 1333 (1917).

67 Akagündüz, "1918-1928 Yılları Arasında...”, s. 336. 
değilken ilahi çare kati bir çaredir. İsmail Bey'e göre İslam ahkâmı feminizme ihtiyaç brrakmaz. İslam kuralları çerçevesinde kadın ve erkek arasında fitrat açısından farklar vardı ve bu nedenle iki cinsin görev ve sorumlulukları da farklıydı. ${ }^{68}$

I. Dünya Savaşı'na kadar yapılan yenilikler ve nihayet savaş koşullarının kadını aileden çıkardığını, ailenin kutsallığını bozup bağlarını çözdüğünü düşünen Sabiha Zekeriya'ya göre kadınlığa dair yapılacak tartışmaların odağında aile meselesi olmalıdır. ${ }^{69}$ Feminizmi devlet ve toplum için bir tehdit olarak algılayan bazı kişilere göre mütareke yıllarının ortaya çıkardığı otorite boşluğu bu akımı güçlendirmişti. Ebuzziyazade Velid bir yazısında savaşların maddi olduğu gibi manevi zararlarına da işaret etmişti. Yazara göre feminizm; savaşla, silahla yenilgiye uğratamayanların başvurduğu bir yöntem olarak milli benliğe ve toplumsal ahlaka zarar verici bir akım olarak yayılmışı. Nitekim kadının hürriyeti adı altında ahlakı bozucu adımlar atılıyordu. Kadın hareketinin ortaya çıkardığı giyim, süs gibi dış görünüşe dair eleştiriler ahlaki boyut çerçevesinde algılanarak Milli Mücadele yılları basınında zaman zaman dile getirildi. ${ }^{70}$ Bununla birlikte kadın hareketinin öncüleri de bu konuda hemcinslerini eleştirmekteydi. Onlara göre kadın, bir takım çevrelerin algıladığı gibi yalnızca moda, güzellik, aşk romanları gibi konular çerçevesinde düşünülmemeliydi. $\mathrm{Bu}$ anlamda kadınlık algısı değiştirilmeliydi. Modern Türk kadını eğitimli, bilinçli, vatansever olmalı, ülkenin içinde bulunduğu olağanüstü koşullarda eğlence, aşk, moda, süs gibi işlerle meşgul olmamalıydı. ${ }^{71}$ Kadının durumuna dair yapılan bir değerlendirmeye göre hayat değişmiş, dolayısıyla kadının dünya görüşü de değişmişti. Bu nedenle kadının konumu eski geleneksel kural ve kaidelerle şekillendirilmemeliydi. ${ }^{72}$

Öte yandan gelenekçiler yenileşme taraftarlarının kadının kamusal alanda yer almasını kadınların hürriyeti ${ }^{73}$ olarak adlandırmasına tepkiliydi. İstanbul'un Kadıköy, Şişli bölgelerinde tiyatrolara giden veya sokaklarda açık şekilde gezen kadınlar en ağır ifadelerle eleştiriliyor, bu durumdan yalnızca kadınlar değil onlara izin veren kocaları, kardeşleri ve aile bireyleri de sorumlu ve suçlu görülüyordu. Hasan Hikmet Bey'e göre "Hürriyete doğru koşan açık kadınlık hiç de fazilete, tekamüle doğru gitmiyor. Belki bu hareketlerle hem kendilerini hem de heyet-i ictimaiyemizi tefessüh ve inkıraza sürüklüyor.” Mutluluğu yuvası dışında arayan kadın medeniyet ve cemiyet için bir inkıraz mikrobu olarak telakki ediliyordu. Dolayısıyla yenilik zarara sebebiyet veriyorsa bu ancak gerileme olarak adlandırılabilirdi. Gerileyen ve sukuta uğrayan milletlerde de bu durum öncelikle kadınlardan başlıyordu. Şimdiki kadınlar aile içi görevleri haysiyet kırıcı olarak görmekte, giyinip süslenmek, gezmek, biraz yabancı dil bilmek, müzik dinlemek gibi işler dışında başka şeyler yapmamaktaydı. O halde bu kadınlardan gelecek için bir şeyler beklenmemeliydi.

68 Sebilürreşad, C. 20, S. 497, 13 Nisan 1338 (1922), s. 30-32.

69 Sabiha Zekeriya, “Kadınlı̆̆ın Hukuku Bahsi”, Büyük Местиа, S. 2, 13 Mart 1335 (1919), s. 29.

70 Akagündüz, "1918-1928 Y1llar1 Arasında...”, s. 337-338.

$71 \quad$ Akdağ, a.g.t., s. 177.

72 Akagündüz, "1918-1928 Yilları Arasında ...”, s. 333.

73 Kadınların erkekler gibi sokaklarda, mağazalarda gezebildikleri halde park, bahçe, pastacı, lokanta vb. yerlerde rahatça dolaşamaması dönemin basınında tartışma yaratan konulardandı. Bu konuda bazı erkek okurların gazetelere şikâyetler ilettiği görülüyordu. Tiyatro gösterilerinin, konserlerin erkek ve kadınlara ayrı gösterimler halinde sunulması, gezinti yerlerinde orta yerden tülle ayrılmış bölümler oluşturulması, vapurlarda, tren ve tramvaylarda bile eşlerin ayrı ayrı yerlerde oturtulması gibi konular fena bir itiyadın mahsulü ve isabetsiz adet ve bidat olarak değerlendirilmişti. Burhan Cahid, "İstanbul Postası", Servet-i Fünûn, S. 1400, 5 Temmuz 1334 (1918), s. 342. 
Neticede son yıllarda boşanma oranlarının artması, binlerce kadının fuhuşa sürüklenmesi, zührevi hastalıkların artması ve doğum oranlarında düşüş yaşanması bu gerilemenin sonucuydu. ${ }^{7775}$

Türk kadınının ahlaki yozlaşma içinde olduğuna dair yabancı basında da bazı yazılar yayımlanmıştı. Halide Edip Büyük Местиa'da ele aldığı bir yazısında belirli bir amaca hizmet amacıyla ortaya çıkan bu tarz yayınlara dikkat çekerek Türk kadınının yüce vasıflarından ve vatanına bağlılığından söz etmişti ${ }^{76} \mathrm{Bu}$ dönemde ahlaki bozukluğun arttığı iddialarına karşı çıkıp zaten uzun süredir toplumun kötüye gidiş gösterdiği düşüncesinde olan yazarlardan Selim Sirrı Bey İstiklâl gazetesinde Ahlak Bozukluğu başlıklı yazısında bir milletin ahlakının birkaç senede bozulamayacağını iddia ederek şikâyetçi olmak yerine çözüm yolları aramak gerektiğini ifade ediyordu. Sebilürreşad dergisi ile bu konuda ihtilafa düşen Selim Sırrı Bey suçun bir diğerine atılmasının zamanı olmadığını düşünüyordu..$^{77}$

Kadının nüfus meselesindeki rolü de zaman zaman basında yer bulan tartışmalardandır. İkdam gazetesinden alıntı yapan Sebilürreşad dergisinde Fransızları Almanlara karşı düşündüren en önemli meselenin nüfus olduğu vurgulanmıştı. Yaklaşık 50 yıl sonra Fransızlar Almanlara oranla önemli ölçüde ekalliyette kalacaktı. "Vatanın gelecekteki muhafazası ancak nüfus ile sağlanabilir" fikrinden hareketle Almanya'nın bu tecrübelerinden yararlanmak amaciyla uzmanlar getirilmesi önerildi. Bu amaçla sanayi şehirleri oluşturulmalıydı. Çünkü pek çok erkek, ailesinin geçimini temin etmek için gurbete çıkmakta, bu durum da doğum oranlarının düşmesine neden olmaktaydı. Bu konuda kadına önemli bir rol biçilmekte, onun aile sahibi olması ile soruna çözüm getirilmektedir. Zira yazara göre bekar kadınlar aile dışında işle meşgul olabilirdi. Buna karşıllık evli kadınların erkek işlerinde çalışması iyi sonuç getirmeyecekti. ${ }^{78}$

Dönemin basınında üzerinde durulan konulardan bir başkası da kurulacak ailenin sağlam temellere dayandırılması gerektiği yönündedir. Bunun için iki tarafın ahlakı, tavırları, ekonomik gücü gibi konularda birbirini tanıması gerektiği belirtilerek sağlıklı nesiller yetişebilmesi için nikâh öncesinde çiftlerin sağlık durumlarının da araştırılması öneriliyordu. ${ }^{79}$ Dönemin basınında az da olsa değinilen bir başka mesele de kadınların spordan uzak duruşunun ortaya çıkardığı olumsuzluklardır. Eski insanların şimdikilere göre nasıl daha sağlıklı bir yaşam sürdürdükleri irdelenen bir yazıda hayat tarzındaki değişikliğin kadının sağlıksız bir hayat geçirmesine yol açtığı değerlendirmesi yapılmış, kapalı ortamlar yerine bol hava, güneş ve sade gıda gibi unsurlara ilave olarak az da olsa spor yapılması kaliteli yaşamın anahtarı olarak görülüyordu. ${ }^{80}$

74 Hasan Hikmet, "İçtimaiyatımızda Garbçılık ve Bozgunculuk: Hürriyet-i Nisvan”, Sebilürreşad, c. 21, S. 530-531, 24 Mayıs 1339, s. 81.1919 yılında İstanbul'da çok sayıda kadın frengiliydi. Ayrıca Anadolu'da da hastalık oldukça yaygındı. Bu yıllarda hastalığa karşı önlemler alınması yönünde gazetelerde çeşitli yazılara yer verildi. İstiklâl, S. 231, 25 Ağustos 1335 (1919); İstiklâl, S. 236, 30 Ağustos 1335 (1919).

75 Burhan Cahid, “İstanbul Postası”, Servet-i Fünûn, S. 1400, 5 Temmuz 1334 (1918), s. 342.

76 Halide Edip, “Türk Kadınları Hakkında”, Büyük Mecmua, S. 15, 13 Teşrîn-i Sânî 1335 (1919), s. 226.

77 Selim Sırrı, “ Ahlak Bozukluğu”, İstiklâl, S. 245, 11 Eylül 1335 (1919).

78 Sebilürreşad, c. 15, S. 366, 22 Ağustos 1334 (1918), s. 31-32. Savaş nedeniyle yaşanan nüfus kaybını telafi etmek için Kadınları Çalıştırma Cemiyeti evlilikleri teşvik edici faaliyetlerde bulunmuştu. Burhan Cahit, “İstanbul Postası”, Servet-i Fünûn, c. 54, S. 1386, 28 Mart 1334 (1918), s. 117; Toprak, a.g.e., s. 9-10.

79 Yunus Fehmi, “Genç Kız ve Kadınlarımızın Hıfz-1 Sıhhatlerine Aid Vesaya-yı Sıhhiye”, İzdivaç, S. 2, 1334 (1918), s. 76.

80 Hayri, “Kadın ve Spor”, Düşünce, S. 1, 15 Şubat 1338 (1922). 
Türk kadını Milli Mücadele yıllarında vatanına karşı hassasiyetini de göstermiş Mondros Ateşkesi'nin ardından başlayan işgalleri protesto eden Türk milletinin en ön saflarında yer almıştı. Ayrıca vatanın kurtuluşu için kadın dernekleri kuran, yardım derneklerinde orduya destek sağlayan Türk kadını bizzat cephede çarpışmış, cephe gerisinde lojistik destek sağlamış, sağlık alanında önemli ihtiyaçları karşılamıştı. ${ }^{81}$ Milli Mücadele yıllarındaki faaliyetleri onun toplumsal yaşamda ön plana çıkmasının bir sonucu olmakla birlikte vatanperverlik duygusunun da tezahürüydü. ${ }^{82}$

\section{Kadın ve Giyim}

I. Dünya Savaşı ve işgal yıllarında basında ortaya çıkan ahlak tartışmalarının odak noktasında kadınların kıyafeti ve aile içi krizler yer aldı ${ }^{83}$ Kadının değişen kıyafeti gelenekçilerle yenilikçiler arasındaki tartışmanın odağındaydı. İçtihad dergisinde bu konudaki fikirlerini ifade eden Rıza Tevfik Bey’in makaleleri Sebilürreşad dergisinde değerlendirilmişti. Çeşitli açılardan hemfikir olunan yazıda Rıza Tevfik Bey'in tesettürün İslam' da yer almadığı iddiası ise eleştirilmişti. Konuyla ilgili vaktiyle Mısır'da Kasım Emin Bey’in yazdığı kitapta da benzer iddialarda bulunduğu, fakat bunun çürütülmesine ${ }^{84}$ rağmen feminizmi savunan Türk kadınlarının bu kitabı referans aldıkları ifade edilerek tesettürün İslam'da farz olduğu ayet ve sünnetlerle desteklenmişti. Yazar, İstanbul kadınlarının içinde bulundukları durumu cahiliye devrinde Arap kadınlarının başörtülerini alelade örtüp, yakalarını açarak gezmelerine benzetmişti. ${ }^{85}$ Tesettürün dini bir kural olduğunu düşünmekle birlikte kadının ilerlemesinin gerektiği ölçüde gerçekleşmediği kanısında olan gelenekçiler de mevcuttu. Bunlardan biri olan Mehmet Tahir'e göre örtünme kadınların ilerlemesinde engel değildir. Nitekim ilerleme eğitim ile olur. ${ }^{86}$

81 İstiklâl, S. 148, 21 Mayıs 1335 (1919); İstiklâl, S. 149, 22 Mayıs 1335 (1919); İstiklâl, S. 150, 23 May1s 1335 (1919); İkdam, S. 8005, 23 Mayıs 1335 (1919), İstiklâl, S. 151, 24 Mayıs 1335 (1919); İnci Enginün, Müjgan Cunbur, Cahide Özdemir, Milli Mücadele'de Türk Kadını, Cumhuriyetin 60. Yıldönümü Yayınlar1, Ankara 1983, s. 14-32, 45-61; Kurnaz, a.g.e., s. 108, 121-124; Kaplan, a.g.e., s. 72-86.

82 Kaplan, a.g.e., s. 86; Zihnioğlu, a.g.e., s.89- 93. Milli Mücadele Dönemi'nde özellikle Eskişehir Savaşlarının ardından cephe gerisinde yararlık gösteren Anadolu kadınlarına ilave olarak gönüllü olarak askere yazılıp cepheye giden kadın sayısında artış görülmüştü. Bu kadınlardan on ikisinin fedakarlığı, cesareti ve vatan sevgisi Ankara Hükümeti tarafından birer harp madalyası ile ödüllendirildi. 1921 yılında Harp Madalyası ile ödüllendirilen kadınlar: İnönü nahiyesi Kurra-i Fındık karyesinden Ali Kerimesi Alime, Selim Kerimesi Şükriye, Hacı Osman Kerimesi Fatma, Musa Kerimesi Ayşe, Mehmed Ali Kerimesi Hafize, Ferid Kerimesi Fatma, Mehmed Kerimesi Ümmühan, Hacı Mustafa Kerimesi Fatma, Veli Onbaşı Kerimesi Ayşe, Manav İbrahim Kerimesi Fatma, Ali Kerimesi Ayşe ve Manav Hasan Kerimesi Fatma Hanımlardır. Resimli Anadolu Hediyesi, S. 4, 1337 (1921).

$83 \mathrm{Bu}$ yıllarda kıyafet üzerinden başlayan serzenişler zamanla eşleri yıllardır cephede olan kadının sadakatinin de sorgulandığı bir süreci ortaya çıkardı. Sadakatsizlik ve ahlaki yozlaşma çeşitli hikayelerde de işlendi. Cafer Ulu, "I. Dünya Savaşı ve İşgal Sürecinde İstanbul'da Yaşanan Sosyal ve Ahlaki Çözülme (1914-1922)", Tarih Dergisi, S. 58 (2013/2), s. 96-99.

84 Mısır'da Kasım Emin'in yazdığı Hürriyet-i Nisvan kitabındaki tezleri çürütmek üzere Ferit Vecdi tarafından bir kitap yazılmıştı. Bu kitabın çevirisinin önsözünü yazan Mehmet Akif’e göre kadınlık meselesi Avrupalıları taklit etmek hevesiyle Müslümanlar arasında yayılmıştı. Çoğu medeniyet kadınlara özgürlük tanınması ve kadın saltanatının egemen olması nedeniyle çökmüştü. Berkes, a.g.e., s. 447.

86 Bu konuda bir çalışma için bk. Feride Yüzer, "Osmanlı Basın Hayatında Mehmet Tahir Bey ve "Çarşaf Meselesi” Risalesi”, Necmettin Erbakan Üniversitesi Illahiyat Fakültesi Dergisi, 42, 2016, s. 327-348. 
I. Dünya Savaşı yıllarında İslam'ın kadının özgürlüğünü kısıtladı̆̆ı ve kadınları sıktığı iddia edilen bazı yayınlar Sebilürreşad mecmuasında sert bir şekilde eleştirilmişti. Nitekim bir takım çevreler İslam kadınlarının "mukaddesat-1 diniyeye ilan-1 harb etmeleri için gece gündüz çalışmaktaydı" ve bu çevrelere göre özellikle tesettür en büyük düşmandı. ${ }^{87}$

Servet-i Fünûn dergisinde Abdülfeyyaz Tevfik tarafindan kaleme alınan bir yazıda "Şeriat tesettürü tarif ve tayin etmiş fakat bunun kalb ve kıyafetini tahdid eylememiştir." denilerek konu farklı bir noktaya çekilmişti. Yazara göre asıl dikkat çekici olan şey örtünmenin amaç değil araç olmasıydı. Neticede "Vakar ve namusa muvafik bir libas bu vazifeyi tamamen görebilir"di. ${ }^{88}$

Örtünme meselesinin bu ölçüde gündem olması esasen kadının kamusal hayatta daha fazla görünür olmasının bir tezahürüydü. Kadın sokaklarda, mağazalarda, işyerlerinde, okullarda göründükçe kıyafeti ile ilgili tartışmalar da sürüyordu ${ }^{89} \mathrm{Bu}$ mesele Milli Mücadele yıllarında da tartışma konusuydu. Beyoğlu'nda tramvaylarda erkeklerin arasında oturan kadınların bu tavrı ve kıyafeti "memleketin mukaddesatına, adatına tezlilkar ihanetler olarak gösterilmekte, hissiyat- ve mukaddesat-1 diniye ve milliyeyi rencide eden bu hadisenin önlenmesi görevi hükümetin en büyük vazifelerinden biri” olarak görülmekteydi. Hatta bu durumdan kadınlar dahi şikâyet etmekteydi. Sebilürreşad dergisinde yayımlanan bir mektupta İstanbul civarında büyük kısmı Türk-Müslüman olduğu için yolculuklarda kadın erkek ayrı yerlerde seyahat ettiği halde Beyoğlu'nda kadınların isteği ile perdelerin kullanılmadığı, kadınlara ayrılmış yerlere oturan erkeklerin kondüktörler tarafından kaldırılamadı $\breve{g}$, dolayısıyla erkeklerin gerekli hürmeti göstermediğinden şikayet edilerek kumpanyanın kadınların taleplerine kulak vermesi, aynı zamanda hükümetten de geleneklerin muhafazasını sağlamak yönünde icraat beklendiği belirtilmişti. İslam ahlakına uymayan, Türk kadınlığ ile ilgisi olmayan bu kadınların "kıyafet-i milliyeden tecerrüd edilmesi" dahi önerilmişti. ${ }^{90}$ Sebilürreşad gibi dergilerin başını çektiği bir grup meseleyi İslam dini açısından değerlendirip tesettüre uygun şekilde giyinilmemesini dine aykırı telakki etmişti. Kadınlar İslam kurallarını bilip ona göre yaşarsa sapkınlıklardan kurtarılabilirdi. ${ }^{91}$ Velid Ebüzziya da Tasvir-i Efkar gazetesinde yayımlanan Tesettür Değil Ahlak Meselesi başlıklı yazısında resmî makamların bu işe el atması gerektiğini ifade etti. Nitekim İngiltere, Amerika gibi ülkelerde bile kadınların kıyafeti resmî bazı kurallarla hükümetçe belirlenmişti. Ona göre bu mesele 4 yıllık harbin ortaya çıkardığ 1 ahlaki bozulmanın ve modaya uyma telaşının bir sonucuydu. ${ }^{92}$

Diğer yandan kadınların uygunsuz ve açık kıyafetler giyindikleri suçlamasıyla karakollara alınması Büyük Мecmua dergisinde eleştirilmişti. 1919 yılı Mayıs ayında Polis Müdüriyeti Zabıta Memurlarının adi bir şüphe ile kadınları karakollara, merkezlere sevk etmesini yasakladı. Bu karar Büyük Meстиа' 'da memnuniyetle karşılandı. Yapılan değerlendirmede uygulamanın sakıncalarına değinilerek memurların kendi dünya görüşlerine göre ahlak bekçiliği yapması eleştirildi. ${ }^{93}$

Sebilürreşad, c. 17, S. 437-438, 21 Ağustos 1335 (1919), s. 171-173.

Abdülfeyyaz Tevfik, “ Kadın ve İslam (Safahat Müellif-i Muhteremine)”, Servet-i Fünûn, c. 56, S. 1438, 4 Kânûn-1 Evvel 1335 (1919), s. 86-87.

Edebiyat-ı Umumiye Mecmuası, c. 2, S. 40, 3 Teşrîn-i Sânî 1917.

Sebilürreşad, c. 19, S. 404-405, 10 Nisan 1335 (1919), s. 142.

Sebilürreşad, c. 17, S. 442, 25 Eylül 1335 (1919), s. 221-222.

Velid Ebüzziya, "Tesettür Değil Ahlak Meselesi”, Tasvir-i Efkâr, S. 2647, 9 Şubat 1335 (1919).

Büyük Местиа, S. 8, 28 Mayıs 1335 (1919), s. 128. 
Servet-i Fünûn dergisinde kadınların erkek tahakkümünden kurtulması gerektiği iddia edilen bir yazıya göre sokaklarda açık şekilde dolaşan, dekolte giyen, fuhuş batağında olan ve çoğu kez hakarete uğrayan kadınların durumunda aile terbiyesinin eksikliği kadar erkek teşviki de etkiliydi. ${ }^{94}$ Ahlak tartışmalarında farklı bir bakış açısı getiren Yusuf Razi ise İstanbul sokaklarında garip kıyafetlerle gezen kadınların ülkedeki kadın nüfusuna oranının oldukça az olduğunu iddia etmişti. Ona göre bu hanımların giyim ve davranışlarını tenkit işi eşlerine, babalarına bırakılmalı; kadınların milli menfaatlere uygun olacak şekilde sosyal hayattaki konumları iyileştirilmeliydi. ${ }^{95}$

Milli Mücadele yıllarında Sebilürreşad Dergisinde yazılar yazan Halide Nusret Hanım kadınların manevi sukut içinde olduklarını düşünüyordu. Özellikle İzmir'in işgalinin ardından İstanbul' da bazı kadınların sokaklarda sürmeli gözler, boyalı dudaklar, şen kahkahalarla dolaşmasını elim ve zelil olarak değerlendirdi. Bununla birlikte bu durumun sorumluluğu yalnızca kadına değil onu bu duruma düşüren erkeğe de yükleniyordu. Ayrıca bu tarz davranışları meşrulaştıran şairler ve bu duruma alkış tutan gazeteciler de bu sukutun müsebbibiydi. ${ }^{96}$ Benzer bir eleştiri yine Sebilürreşad dergisinde yer bulmuştu. Marmara sahillerine gelen muhacir kafileleri yatacak yer, yiyecek lokma, giyecek bir parça bulamazken İstanbul Beyoğlu’nda bazı kadınların “münevverlik bahanesiyle süse ve sefahate dalarak mesirelerde, tiyatro, sinema gibi yerlerde zevk ve sefa ile meşgul olup hatta ecnebilerle kol kola gezmeleri, tahsil görmüş bazı kadınların zevk ve sefahat aleminde avuç avuç para harcamaları” eleştirilmişti. Yazara göre bu durumun önü alınamazsa söz konusu bölgede İslamiyet yok olma tehlikesiyle karşı karşıya kalacaktı. Fakat burada sorumluluk bir başka zümreye, yenilik taraftarlarına yüklenmişti. Bu zümrenin yaptığg çalışmalar, yayınlar ve eserlerle, konferanslar, teşkilatlar ve emrivakilerle kadınları etkiledikleri hatta bu amaçla İslam'ın oldukça hak verip ileri götürdüğü kadının tesettürünü bile Hristiyan âdeti ilan ettikleri iddia edilmişti. Bu salgının Anadolu’ya sıçramasından endişe edilerek Büyük Millet Meclisinin tedbir alması temennisine de yer verilmişti. Çünkü bu zihniyet basın yoluyla Anadolu'ya sirayet etmeye başlamıştı. Hatta yabancılarla işbirliği içinde olan kişiler kadınların bir kısmını özel görevlerle Anadolu'ya göndererek Anadolu Hükümetini halkın gözünden düşürmeye çalışıyordu. Nitekim kadının kıyafetindeki değişim ve İstanbul'un bazı semtlerinde ortaya çıkan yaşam tarzı bir terakki ve tekamül değil ahlak çöküntüsüydü. ${ }^{97}$

Celal Sahir de Servet-i Fünûn dergisinde yayımlanan bir yazısında kadının kıyafeti meselesini irdelemişti. Ona göre kadının kıyafeti üzerinden süregelen tartışmalarda toplumu oluşturan bu iki unsurdan birinin diğerine vesayeti gereksiz ve haksızdı. Ayrıca kadın meselesinin bir din meselesi gibi algılanması da doğru değildi. Dinin kadın meselesine bakışı ahlaki açıdandı. Yazara göre mesele kadınların giyinmesi değil soyunması meselesiydi. Burada da suçlu modaydı. Celal Sahir yazısında bütün dünyada ahlaki bir buhran olduğunu ve en çok değerini yitiren şeyin de haya duygusu olduğu belirtiyordu. Bununla birlikte moda tutkusunun geçici olacağını ve Türk kadının kendine gelip bu rüzgardan kurtulacağını ümit etmekteydi. Kadın kıyafeti konusunda dile getirilen milli kıyafet ${ }^{98}$

94 Safi, “Kadınlar, Erkekler”, Servet-i Fünûn, c. 57, S. 1464, 21 Teşrîn-i Evvel 1336 (1920), s. 86-87.

95 Yusuf Razi, “ Harpten Sonra Kadınlar”, İstiklâl, S. 105, 8 Nisan 1335 (1919).

96 Halide Nusret Kâzımi, “Müslüman Kadını Nasıl Olmalı?”, Sebilürreşad, c. 17, S. 423-424, 19 Haziran 1335 (1919), s. 63.

97 Sebilürreşad, c. 19, S. 485, 25 Haziran 1337 (1921), s. 182-184.

98 Türk kadınının kendine özgü bir kıyafeti olması yönünde İnci dergisinde yazılar yazan Zehra Hakk1 
oluşturulması, bunun için komisyonlar kurulması veya kanunlar çıkarılması yönündeki mücadele usullerini de "Eğer gülmek için değilse, acınacak bir hal" şeklinde yorumlamıştı. ${ }^{99}$

Türk kadını batının moda gazeteleri, reklam ve katalogları ile zehirlenmiş, ayrıca bazı Türk yayımcıları da teşvik edici yayınlarla bu olumsuz duruma katkı sunmuştu. Böylelikle "Türk kadınına ihanet edilmişti." "100 İstanbul'un işgal yıllarında bazı kadınların kıyafetlerinden rahatsız olan Sebilürreşad dergisi çeşitli neşriyatlarla bu konuda kadınlara destek veren yayınlara karşı bir mücadele başlattı. Bu mücadele esnasında yayımlanan yazılarda İstanbul kadınlarının bir kısmının Frenkleşmekte olduğu iddia edilerek bunu özellikle basında şiddetle destekleyen, batı medeniyetini ülkeye sokmaya çalışanlara çeşitli isnatlarda bulunuldu. İstanbul'da ahlakın sukuta uğradığını iddia eden dergi bu konuda Yahya Kemal'in görüşlerini yayımlamış ve işgalin sonuçlanması ile birlikte bu ahlaksızlığa sebep verenlerin cezalandırılacağını ileri sürmüştü. ${ }^{101}$

Gelenekçiler görüşlerini desteklemek amacıyla geleneklerine bağlı kalarak ilerleme sağlamış ülkelerdeki uygulamaları ve onların Türk kadınına bakışını okuyucuya iletmekteydi. Sebilürreşad dergisi 1923 yılı başlarında Türkiye'de bulunan bir Japon profesörle yapılan röportaja yer verdi. Japon profesöre göre özellikle İstanbul kadını modaya düşkünlüğü ile göze çarpmaktaydı. Ankara ve diğer bazı Anadolu şehirlerinde de kısa süreli seyahatler yapan profesör tesettüre bağlı olmakla birlikte İstanbul kadınlarının gereksiz bir kıyafet lüksü içinde olduğunu düşünüyordu. Ona göre Japon kadını kıyafet konusunda tutumluydu ve ekonomik açıdan sıkıntı yaratacak şekilde parasını sokaklara atmiyordu. ${ }^{102}$

Bununla birlikte kadının kıyafetindeki değiş̧imin yaşam tarzının ortaya çıkardığı bir sonuç olduğu, bu anlamda bir mecburiyetten kaynaklandığ düşüncesinde olup konuya olumlu yaklaşan bir kesim de mevcuttu. ${ }^{103}$ Kadınların boyanması ve kıyafeti üzerinden basın aracılığı ile yapılan eleştirilerin yersiz olduğunun ifade edildiği bir yazıda "Sanki erkeklerimiz muayyibden, nekaisden münezzeh kalmış gibi kadınlarımızın kusurlarını meydana çıkarmaya çalışıyoruz." ifadeleri kullanıldı. Kadınların boyanmasının sorumlusu erkeklerdi ve onların farkında olmadıkları bu çirkinliği önlemek, gerçek zerafetin, bedii zevkin inceliklerini öğretmek için dersler, konferanslar verilmeliydi. Kadınlara yönelik felsefi konular, edebiyatta kadın, kadının ahlaka etkisi gibi konferansların yanında muaşeret terbiyesi, zevk ve sanat duygusu, ev ve aile muhabbeti gibi konularda dersler verilmeliydi ki bu daha büyük bir hizmet olacaktı. Dolayısıyla yazar erkeklerin bu konudaki sorumluluklarını yerine getirmeden kadınların aşırı süslenmelerine karşı söz söyleme

Hanım'a göre milli kıyafet; " Güzelce başı örtmek için bir başörtüsü, sonra bir palto, rop manto nev’inden bir boy urbası!. Zannediyorum ki en eski biçiminde bir çarşaf bile bunun kadar tesettürü temin edemez.” sözleriyle tarif edilmişti. Toprak, a.g.e., s. 259.

99 Celal Sahir, “Kadın Kiyafeti”, Servet-i Fünûn, c. 57, S. 1474, 23 Ağustos 1336 (1920), s. 206-207.

100 Sebilürreşad, c. 20, S. 459, 27 Nisan 1338, s. 54-55.

101 Yahya Kemal'e göre Şark dünyası kadınlarının örnek aldığı ve İslam kadınları arasında en üst seviyede yer alan Türk kadını son elli yıldan beri yavaş yavaş alafrangalaşmış ve eski mevkiini kaybetmişti. Bu durumun daha da kötü olacağını düşünen Yahya Kemal Abdülhamit ve Abdülaziz devirlerinde Türk kadınlığının çok fazla tekâmül ettiğini ve eğer bu tekamül devam etseydi Türk kadınının özgürleşip Avrupa kuklası olmayacağını iddia etmişti. Ona göre mevcut durumda bütün Türk kadınları İstanbul kadınları gibi olsa Türk milleti 40-50 yılda yok olabilirdi. Sebilürreşad, c. 20, S. 512, 3 Ağustos 1338 (1922), s. 214-215.

102 Sebilürreşad, c. 21, S. 540-541, 28 Haziran 1339 (1923), s. 167-168.

103 Ulu, a.g.m., s. 96. 
hakkının olmadığını iddia etmişti. ${ }^{104}$

Konuya farklı bir açıdan bakan bir yazıda ise eski Türklerde kadının giyimi, süslenmesi, evlilik adetleri konu edinilmiş, basının bu konu üzerinde gerektiği gibi durmadığı vurgulanmıştı. Yazar eski Türk kadınının en üst düzey devlet yönetimine gelebildiğini, sokağa rahatça çıkıp, başına bir örtü veya yaşmak taktığını dile getirerek giyim, süs, takı, evlilik adetleri gibi konulara Divan-ı Lügat-1t Türk’ten örnekler vermişti. ${ }^{105}$

\section{Kadın ve Siyasi Haklar}

Birinci Dünya Savaşı sonlarında dünyanın çeşitli ülkelerinde kadına siyasi haklar verilmesi de basında sıkça yer bulmuş, Türk kadınının da bu haktan faydalanması arzusu dile getirilmişti. ${ }^{106}$ Savaşın sonlarında kadın meselesinin tüm dünyada oldukça hızlı bir şekilde gelişme göstermesi savaşın sonucu olarak değerlendirilmişti. Zira savaş, kadın ve erkek arasındaki bedensel farkların sanıldığı kadar uçurum teşkil etmediğini ortaya koymuş, ${ }^{107}$ bu anlamda toplumsal yapıda kadınlar lehine önemli değişimler getirmişti. ${ }^{108}$

Savaş yıllarında Türk kadınının sosyal yaşamdaki yeri tartışmaları sürerken diğer yandan Avrupa'da veya dünyanın çeşitli bölgelerinde kadınların durumuna dair değerlendirmelerin amacı olanı değil olması isteneni ve bekleneni kamuoyuna sunmaktı. ${ }^{109}$ İstanbul'da yayımlanan Osmanicher Lloyd adlı Alman gazetesi de Türk kadınlığının değişimini ele alan yazılara yer verdi. Bu yıllarda Sabah, Tanin gibi gazetelerde de Türk kadınlığına dair yazı dizileri yayımlandı. $\mathrm{Bu}$ yazılarda özellikle batı kadınlarının elde ettiği, sosyal, hukuki ve siyasi haklardan sıklıkla bahsedildi. ${ }^{110}$ Buna mukabil Türk toplumunun kadın ve kadınlık meselesini medeni bir şekilde halledememiş olmasının yeniliklerin ve ilerlemenin gerektiği gibi gerçekleşmemesinde etkili olduğu iddia edildi. Nitekim Türk kadını henüz ekonomik ve sosyal haklarını gerektiği gibi elde edememişti. Sabah gazetesinde konuyla ilgili yazılar yazan Ahmet Emin Bey kadınların meslek hayatında geri kalmasının nedenini sıkı taassuba bağlamakta olağanüstü devirlerin bu alanda önemli değişiklikler oluşturduğuna işaret etmekteydi. Bununla birlikte Türk kadınının haklar elde edip kamu hayatında yer almalarının batıdaki gibi doğal bir süreçle tamamlanacağı konusu tartışmalı meselelerdendi. Zira Meşrutiyetle birlikte pek çok yenilik ortaya çıksa da kadına kamu hayatında serbest bir şekilde yer verilmediği sürece bunun gerçekleşmesi beklenemezdi. ${ }^{111}$

Türk kadının seçme ve seçilme hakkına sahip olması Milli Mücadele yıllarında da dillendirilen meselelerdendir. Savaşta babasını, eşini, evladını, kardeşini vatan uğrunda şehit veren

104 Burhan Cahid, "İstanbul Postası“, Servet-i Fünûn, S. 1396, 30 Mayıs 1334 (1918), s. 262.

105 Hüseyin Namık, “Tarihte Türk Kadınlığı”, Dergâh, S. 22, 5 Mart 1338 (1922), s. 156.

106 Servet-i Fünûn, c. 51, S. 1305, 9 Haziran 1332; Servet-i Fünûn, c. 51, S. 1326, 10 Teşrîn-i Sânî 1332 (1916), s. 309; Servet-i Fünûn, c. 52, S. 1338, 1 Mart 1333 (1917), s. 156.

107 Halil Hamid, Dünkü, Bugünkü, Yarınki Kadın, Necm-i İstikbal Matbaası, İstanbul 1334, s. 15-21; Kazım Nami, “Harp ve Kadın”, Donanma, S. 80, 28 Temmuz 1333 (1917); Sabiha Zekeriya, “Türk Kadınlı̆̆ının Terakkisi”, Вüyük Местиа, S. 1, 6 Mart 1335 (1919).

108 Zihnioğlu, a.g.e., s. 82.

109 Servet-i Fünûn, c. 50, S. 1287, 4 Şubat 1331 (1916), s. 164.

110 M.S., "Kadınlar ve Kadınlık Meselesi”, Servet-i Fünûn, c. 52, S. 1342, 5 Nisan 1333 (1917), s. 232-233.

111 M. S., "Kadınlar ve Kadınlık Meselesi”, Servet-i Fünûn, c. 52, S. 1343, 12 Nisan 1333 (1917), s. 256-257. 
ve vatan aşkı ile çarpan yüreklerin de siyasi alanda erkekler kadar hak sahibi olduğu fikri Büyük Местиа dergisinde Sabiha Zekeriya tarafindan dile getirildi. Ona göre erkekler kadar hatta belki de onlardan fazla vatana bağlı ve aşık kadınların bu heyecanı canlı bir şekilde yaşayamaması, vatana kurban ettikleri milyonlar adına olsun ülkeye ait düşünce ve fikirlerini söyleyememeleri hem günah hem de eziyetti. Konuya dair yerleşmiş kanılardan biri olan kadınların liyakatsiz olduklarını ve siyasi meselelere karışacak derecede rüştlerini ispat etmediklerini iddia eden görüşü de eleştiren yazar "Meşrutiyet ilan edildiği günden beri on sene geçtiği halde erkeklerimiz bu rüşd-i siyasiye sahip olduklarını ispat edebilmişler midir? Şu halde böyle erkekler için de varid bir sebeble kadınları intihab hakkından mahrum etmek hodkamlıktan başka bir şeyle tefsir edilemez." ifadelerini kullanmakta ve bu hakkı elde etmek için mücadeleye hazır aydın ve donanımlı kadınlık bulunduğunu belirtmekteydi. ${ }^{12}$

\section{Sonuç}

Osmanlı toplumunda nüfusun önemli bir kısmını oluşturan kadınların hak talepleri II. Meşrutiyet ile birlikte canlandı. Basın hayatı ile hız kazanan bu hareket zamanla hak talebinden pratiğe döküldü. Bununla birlikte kadın hakları, eğitimi, kadının toplumsal konumu dönemin basınında gelenekçilerle yenileşme taraftarlarının tartışma konularının odağında yer aldı. II. Meşrutiyet ile birlikte yoğunlaşan kadın hareketi I. Dünya Savaşı yıllarında farklı bir boyuta taşındı. Kadınlar erkeklerin cephede yer almasıyla çalışma ve eğitim hayatında daha da görünür oldular. $\mathrm{Bu}$ durum geleneksel yaşamdan farklı olarak dünya görüşünde, giyiminde ve yaşam tarzında değişimleri ortaya çıkardı. Kamu hayatında daha fazla yer alan, eğitim hakkını kullanan kadın ve kadınlık savaş süresince dönemin basınının önde gelen başlıklarındandır.

Kadın ve kadınlık meselesi aydın ve yazarlartarafından gelenekçilik, modernlik ve milliyetçilik temelinde irdelendi. Bu süreçte kadının kamusal alanda daha görünür olmasının da etkisiyle en sık yer verilen konu eğitim ve kıyafet ile ilgili tartışmalar olarak karşımıza çıkmaktadır. Konuya İslami bakış açısı ile yaklaşan gelenekçiler ile devrin değiştiğini düşünen yenileşme taraftarları meseleyi kendi dünya görüşlerine göre okuyucularına aktardılar. Kadının çalışma hayatına girmesiyle onun geleneksel aile yapısındaki görevini aksatacağını düşünen gelenekçilerin aksine savaşın ortaya çıkardığı ekonomik zorluklar dolayısıyla artık kadının çalışmasının elzem olduğunu düşünen yenilikçiler de fikirlerini kanıtlamaya ve kamuoyunu yönlendirmeye çalıştılar. Dönemin yazınına bakıldı̆̆ında tartışmaların odağında yer alan ve kadının asli görevi olarak görülen annelik, bakış açıları farklı da olsa iki tarafın da ön plana çıkardığı en kutsal görevdir. Nitekim annelik görevinin gerektiği şekilde yerine getirilmesi gelecek nesillerin en iyi şekilde yetişmesi demekti.

$\mathrm{Bu}$ dönemde kadınlar kadar modernleşme yanlısı erkekler de kadının özgürlüğünü savundu. Gelenekçi çizgideki basında kadın hareketi İslam kuralları çerçevesinde olumsuz yaklaşımla yorumlanarak bu harekete karşı çıkıldı. Ayrıca gelenekçi erkekler kadar, bazı kadınlara göre de ataerkil toplum yapısına bağlı kalınarak kadının konumu biçimlenmeliydi. Bununla birlikte kadınların en çok sorguladığ 1 ve değişmesini arzu ettiği konu ise ataerkil toplum yapısının ortaya çıkardığı erkek egemen kurallardı.

112 Sabiha Zekeriya, “Kadınlar ve İntihabat”, Büyük Мecmua, S. 14, 30 Teşrîn-i Evvel 1335 (1919), s. 218219. 
Savaş, kadının toplumsal rolünün sorgulanmasına zemin hazırladı. Bu durum Milli Mücadele yıllarında kadının gerek cephede gerekse cephe gerisinde daha aktif yer almasını sağladı. Nitekim Milli Mücadele yıllarında mitingler başta olmak üzere ön saflarda yer alan kadınlar kurdukları derneklerle kurtuluş için çareler üretti. Gerek I. Dünya Savaşı'nda gerekse Milli Mücadele yıllarında vatanın her meselesinde ön saflarda yer alan Türk kadınının gösterdiği fedakarlıklar Cumhuriyet Dönemi'nde eğitim başta olmak üzere, sosyal ve siyasi haklar verilmesinde ve talep ettiği hakların kazanılmasında etkili oldu.

\section{Kaynakça}

\section{Gazete ve Dergiler}

Alemdar

Büyük Местиа

Dergah

Donanma

Düşünce

Edebiyat-ı Umumiye Mecmuası

İçtihad

İkdam

İktisadiyat Mecmuası

İslam Mecmuas1

İstiklal

İzdivaç

Kadınlar Dünyası

Mefkure

Meclis-i Mebusan 3. Dönem Tutanak Dergisi

Muallim

Musavver-i Malumat-ı Nafia

Ocak

Resimli Anadolu Hediyesi

Sebilürreşad

Servet-i Fünûn

Tasvir-i Efkâr

Türk Kadını

Yeni Местиа 


\section{Kitap ve Makaleler}

Akagündüz, Ümüt, “1918-1928 Y1lları Arasında Yayımlanan Kısa Ömürlü Osmanlıca Kadın Dergileri Hakkında Bir Değerlendirme”, Kebikeç, 34, 2012, s. 323-346.

, “Kadın ve Kadınlığa Dair II. Meşrutiyet Dönemi Dergilerinden Yansımalar (1908-1918)", Folklor/Edebiyat, 19/73( 2013/1), s. 63-80.

Akdağ, Çilem Tuğba, KadınDergilerinde KadınModernleşmesi (1869-1927), Yayımlanmamış Doktora Tezi, Erciyes Üniversitesi Sosyal Bilimler Enstitüsü, Kayseri 2015.

Aydın, Mehmet Akif, "Hukuk-1 Aile Kararnamesi", Diyanet Vakfi İslam Ansiklopedisi, C.18, İstanbul 1998, s. 314-318.

Berkes, Niyazi, Türkiye'de Çăğdaşlaşma, yay. haz. Ahmet Kuyaş, 18. Baskı, Yapı Kredi Yayınları, İstanbul 2012.

Çakır, Serpil, Osmanlı Kadın Hareketi, Metis Yayınları, İstanbul 1996.

Çeker, Orhan, "Hukuk-1 Aile Kararnamesi Giriş ve Tarihçesi”, Mehir, İlkbahar 1999, s.1921.

Enginün, İnci- Cunbur, Müjgan- Özdemir, Cahide, Milli Mücadele’de Türk Kadını, Cumhuriyetin 60. Yıldönümü Yayınları, Ankara 1983.

Halil Hamid, Dünkü, Bugünkü, Yarınki Kadın, Necm-i İstikbal Matbaası, İstanbul 1334.

Kaplan, Leyla, Cemiyetlerde ve Siyasi Teşkilatlarda Türk Kadını (1908-1960), Atatürk Araştırma Merkezi Yay., Ankara 1998.

Köksal, Ahmet, “Savaş ve Duygusal Değişim: Birinci Dünya Savaşı’nın Sonunda Osmanlı Basınından Bir Panorama Denemesi”, Zamanın İzleri: 100. Yılında Birinci Dünya Savaşı, Karadeniz Teknik Üniversitesi Yayınları, Trabzon 2015, s. 103-121.

Kurnaz, Şefika, Cumhuriyet Öncesinde Türk Kadını (1839-1923), 2. Bask1, T.C. Başbakanlık Aile Araştırma Kurumu Başkanlığı Yayınları, Ankara 1991.

Maruf Er-Rusafi (Müntefik Mebusu), Erkekle Kadın Arasında Müsavat Olabilir mi?, Evkaf Matbaas1, İstanbul 1333.

Toprak, Zafer, Türkiye'de Kadın Özgürlüğü ve Feminizm (1908-1935), Tarih Vakfi Yurt Yayınları, İstanbul 2016.

Ulu, Cafer, "I. Dünya Savaşı ve İşgal Sürecinde İstanbul'da Yaşanan Sosyal ve Ahlaki Çözülme (1914-1922)", Tarih Dergisi, S. 58, (2013/2), s. 87-129.

Uyanık, Necmi, "Batıcı bir Aydın Olarak Celal Nuri İleri ve Meşrutiyet'ten Cumhuriyet'e Türk Kadınına Bakışı”, Selçuk Üniversitesi Türkiyat Araştırmaları Dergisi, S. 36, Güz 2014, s. 137-161.

Van Os, Nicole A.N.M., "Aiding the Poor Soldiers' Families: The Asker Ailelerine Yardımc1 Hanımlar Cemiyeti”, Türkiyat Mecmuası, c. 21, Güz 2011, s. 255-289.

Yazıc1, Abdurrahman, “Osmanlı Hukuk-1 Aile Kararnamesi (1917) ve Sadreddin Efendi’nin 
Eleştirileri”, Ekev Akademi Dergisi, S. 62, Bahar 2005, s. 567-584.

Yüzer, Feride, "Osmanlı Basın Hayatında Mehmet Tahir Bey ve "Çarşaf Meselesi” Risalesi”, Necmettin Erbakan Üniversitesi İlahiyat Fakültesi Dergisi, 42, 2016, s. 327-348.

Zihnioğlu, Yaprak, Kadınsız Inkılap: Nezihe Muhiddin, Kadınlar Halk Fırkası, Kadın Birliği, Metis Yayınları, İstanbul 2016. 